\title{
متطلبات تحقيق التزبية البيئية لدى طلاب المعاهد الثانوية الأزهرية
}

\section{داليا فاروق الطغازي أحمد}

المقدمة :

مشكلات وما يهددها من أخطار و القادر على أن يسهم في حمايتها وصيانتها.

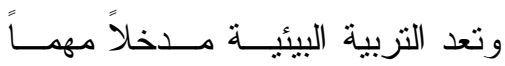

لترشيد سلوك الإنسان تجاه البيئة ومواردها،

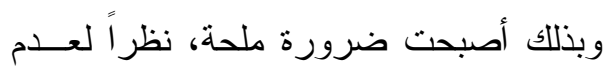

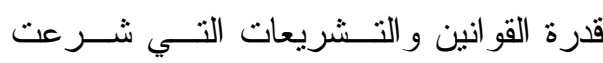
لحماية البيئة على الحد من المشكلات البيئية

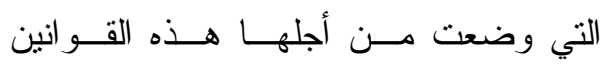
و التشريعات، فهي لم تستتد إلى وعي و إدر الك يصل إلى ضمير الإنسان، ويتحول لديه إلى في قيم إيجابية وضو ابط للسلوك تجعله يحـافظ

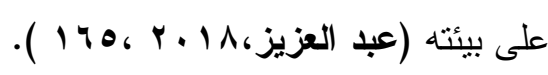

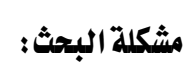

يشهر عالمنا المعاصر انفجار ا سكانيا

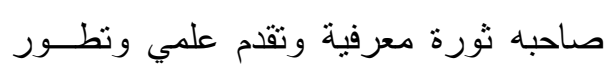

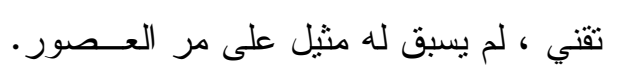

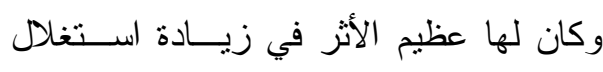

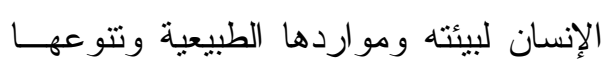
الحيوي. وقد أدى ذلك لاختلال في توازنها. مما ترتب عليه ظهور العديد من المشكلات و المخاطر البيئية، التي لم تقتصر على قـــارة
لقد ارتبطت حياة الإنسان بالبيئة التي

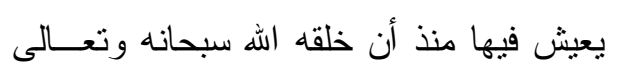

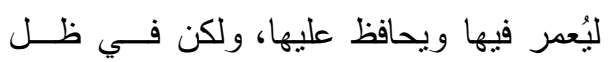

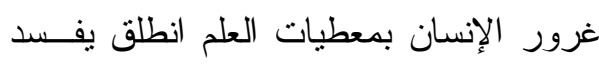

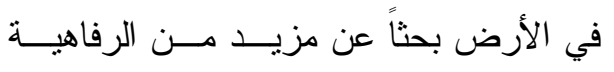

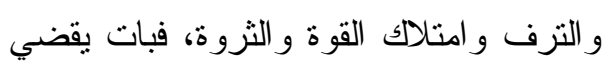

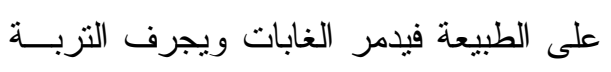

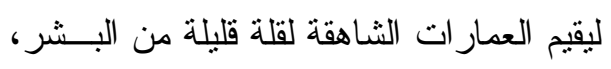

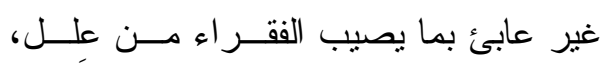
و انطلق ينقن العديد مــن الــصناعات التــي تطارد عو ادمها ما يدمر الهو اء اللازم لحيــاة

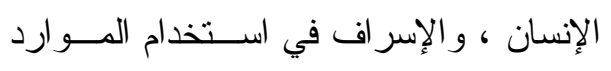

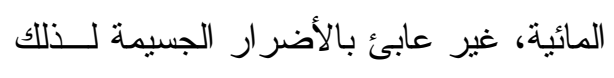

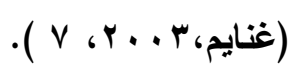

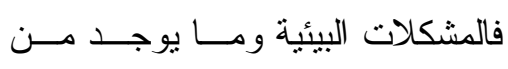

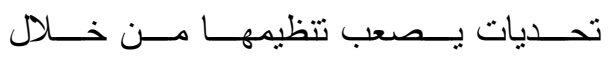

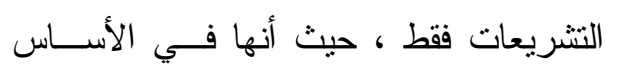

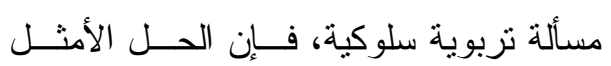

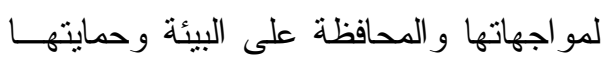
يكمن في حسن تتشئة الإنسان المتفهم لبيئته ،

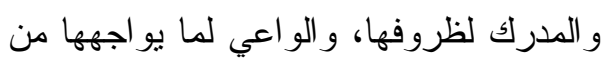


وبالرغم من ذللك يجد الناظر في كتب

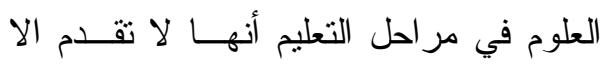
القليل من الموضوعات في هذا الثأن ، وان وجدت فهى تعالجها بصورة بصورة معرفية

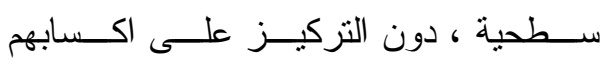
اتجاهات ايجابية نحو بيئتهم و القيم الداعمــة الى الاهتمام بها وحو افز المشاركة النـشطة في تحسينها وحمايتهــا وممارســـة الـسلوك كـ السوي نحوها واتخاذ القــرار ات المناســبة حيالها .وبالتالي تدنى الوعي البيئـي لــدى الطلاب ، الامر الذي يــؤدي الــى غيــاب التعامل المناسب مع البيئة .

ومن خلال ما سبق يحــاول البحـــث

الحالي التوصل الى متطلبات تحقيق التربيــة

البيئية لدى طلاب المعاهد الثانوية الازهرية وقد أمكن صياغة مشكلة البحث في السؤال

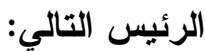

ما متطلبات تحقيق التربية البيئية لدى طلاب المعاهد الثانوية الاز هرية ؟

ويتقر ع من السؤال الرئيس الاسئلة الفرعيــة التالية: - 20 - n (1) ما الاطار الفكري و الفلسفي للتربية

\section{البيئية؟}

(Y) ما أبرز مشكلات التربية البيئية لدى طلاب المعاهد الثانوية الأزهريــة وكيف يمكن مو اجهتها؟
دون أخرى. أو منطقة دون غيرها ـ فـــل

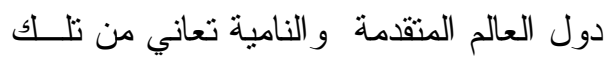

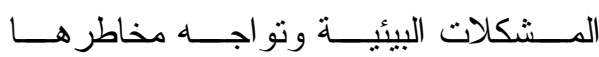
المختلفة(الدوسري، Y I . r ، I ) . فالتربية البيئية هى الوسيلة الرئيـسة

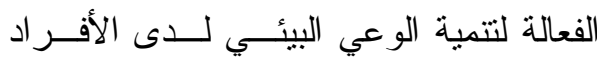
و اكسابهم القــيم البيئيــة و الــسلوك البيئـي

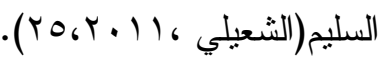

وقد أوصت العديد مــن الدراســات بضرورة الاهتمــام بالتربيــة البيئيــة لــدي

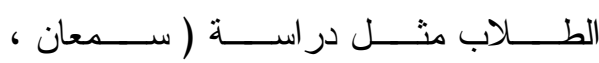

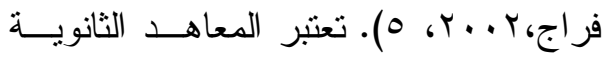
الأزهرية التي يوكل اليها الوعي بالمشكلات كمدخل لسلوك الطلاب نحو البيئة لذلك فــان دمج الجوانب البيئية بـشكل منكامسلـ فـي المناهج الدراسية تؤدي الى ربطهـــا بواقـع حياة المجتمع وذات معنى للمتعلم . ويعد استتز اف الموارد البيئية أزمـــة وعي وقيم فهى بالدرجة الأولـى ســلـوكيات ناتجة عن غياب الــوعي والقـيم المتعلقــة بطريقة معاملة الانسان مع البيئة فـي حـين أكدت بعض الدر استات على وجــود بعــض المشكلات التي تواجه تحقيق التربية البيئيــة

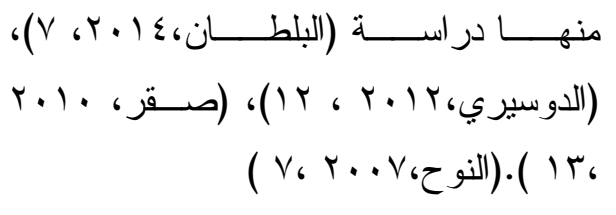


الدراسات السابقة:

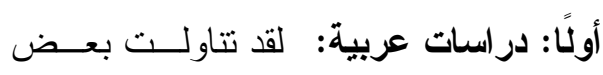

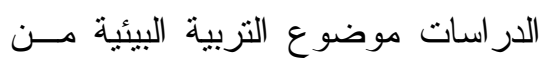

$$
\text { عدة زو ايا من هذه الدراسات : }
$$

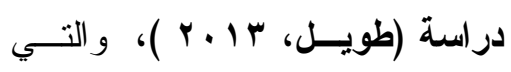

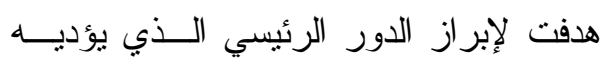

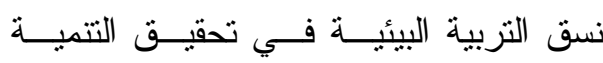

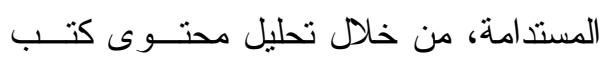

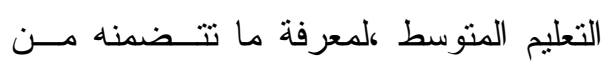

توجيهات قيميــة ومنطلقـــات الحاجة لمفاهيم

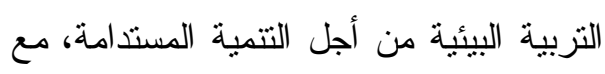

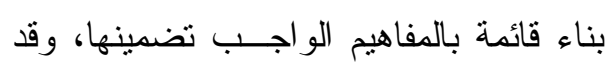

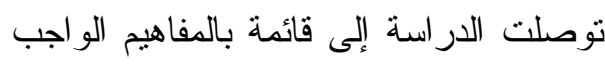

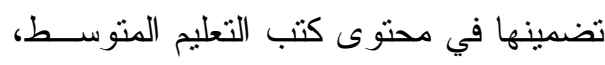

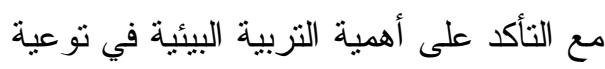

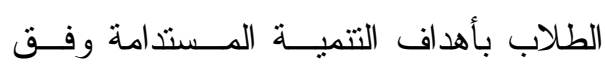
استر اتيجية الثربية البيئية من أجــل التتميـــة

$$
\text { المستدامة. }
$$

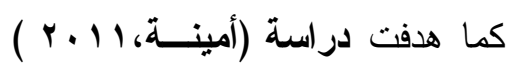

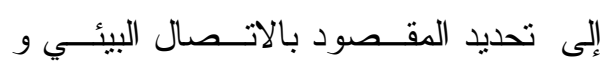

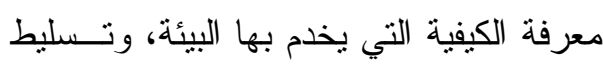

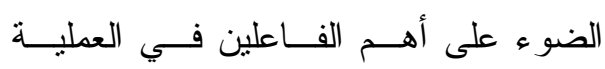
الاتصالية البيئي، نوضيح المساهمات التـي يساعد بها هؤلاء الفاعلين في إحداث اتصال

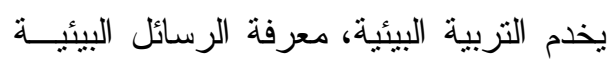
و الكشف عن الجماعات المستهدفة بها، فهـ

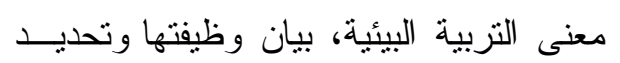

(ץ) ما التصور المقترح للتغلــب علــى

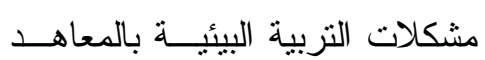

الثانوية الأزهرية ؟ لمئل

\section{هدف البحث:}

يهذف البحث الحــالي إلــى وضــع

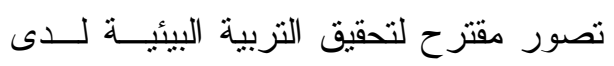
طلاب المعاهد الثانوية الأزهرية.

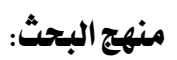

اســـتخدم البحـــث الحــالي المــنهـج

الوصفي وذلك لملائمته لطبيعة الدر اسة وذلك من خلال التعرف على ماهية التربية البيئيــة

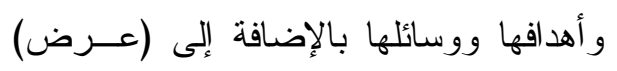
المشكلات التي تواجه تحقيق التربية البيئيـــة

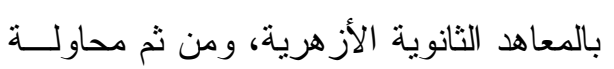
وضع تصور مقترح لتحقيق التزبية البيئيــة

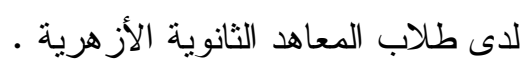
مصطلح البحث:

يعرف البحث الحالي التزبية البيئيــة

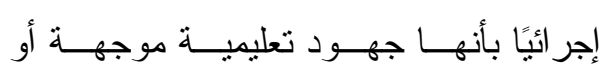
مقصودة، نحو تعريف وتكــوين المــدركات

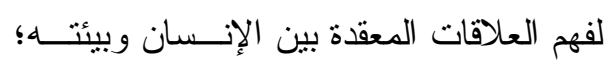

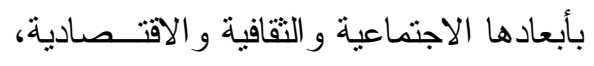
و البيولوجية و الطبيعية، حتى يكـــون و اعيــا

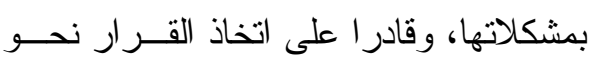

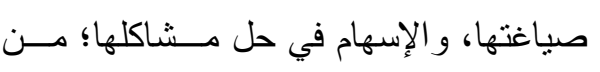

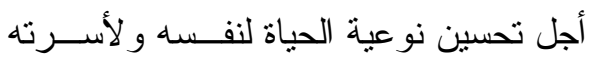
و المحيطة وللعالم. 
معايير التربية البيأيــة ، حيــث اســتخدمت الدراسة المنهج الوصفي من خـــلال تحليـلـل

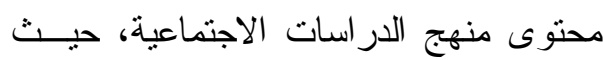

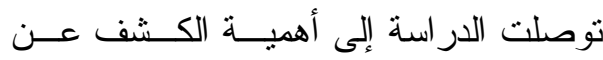

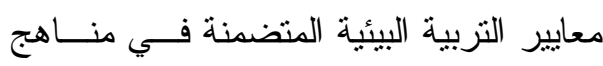

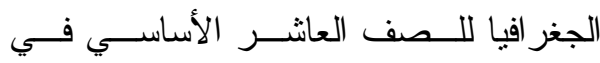
الأردن، تقديم وحدة تعليمية مطورة في ضوء

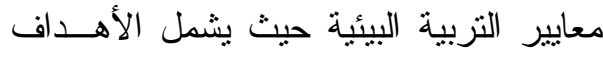
و المحتوى و الاساليب و الانشطة و النقويم.

في حين هــدفت دراســة (رجـب،

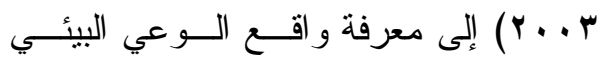

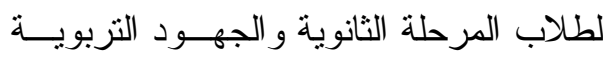
لتتمية الوعى البيئي لديهم وتحليــل الابعــاد التربوية للتشريعات البيئية مع وضع تصور لئي

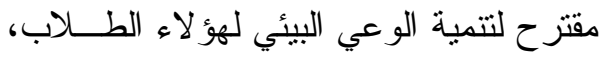
وطبقت هذه الدراسة على • VY طالبا وطالبة من الصف الثاني الثانوي العام و الفن بأقسامه

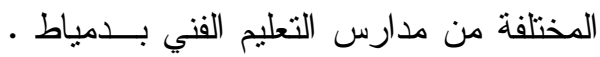

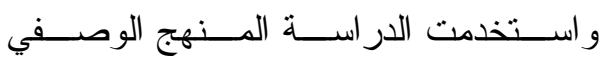

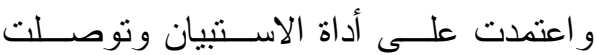
الدر اسة إلى عدم وجود فروق دالة إحصائيا بين متوسطي درجات الذكور و الاناث وبــين

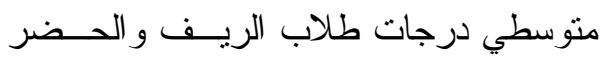
وبين متوسطي درجات طلاب التعليم الثانوي العام وطلاب الثانوي الفني. وقــد هــدفت دراســـة (الحسـسيني،

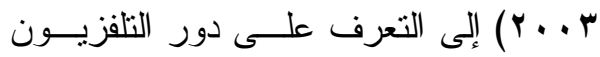

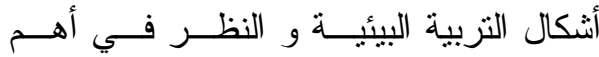
القائمين بالعملية التعليمية فيها. وقد استخدمت

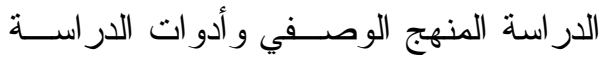
تمنلت في المقابلة العلمية وتوصلت الدراسة ولت لهن إلى وجود وعي سياسي و مجتمعي بأهميــة التربية البيئية و كذا بأهمية الاتصال البيئـي وني لئي لكن على غرار التربية البيئية. في حين هــدفت دراســة ( لطفــي،

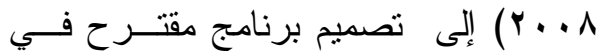
التزبية البيئية في مجال العلوم، التعرف على لفى لقدئ

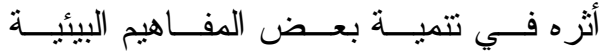

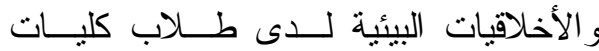
التزبية، وتحديد المفاهيم و الأخلاقيات البيئيـــة التي يجب نو افر ها لدى طلاب كلية التربيــة و استخدمت الدراسة المنهج التجريبي حبــث تكوين من عينة الدراسة من عينة من طلاب الفرقة الأولي بكلية التزبية جامعة الزقــازيق وبلغ عددها or طالب وطالبة .وقد أعــدت

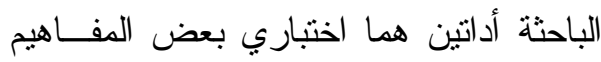

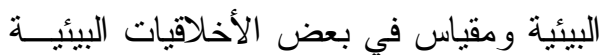
وتوصلت الدراسة إلــي فعاليــة البرنــامج المقترح في تتمية بعــض المفــاهيم البيئيــة

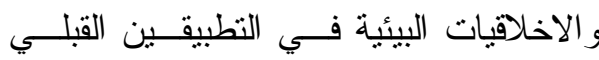

$$
\text { و البعدي • }
$$

بينما هدفت دراسة (جمعة، V . . Y )

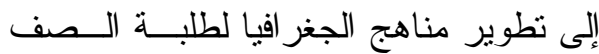

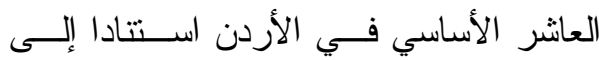


التطبيق القبلي و البعدي و استمارة ملاحظــــة

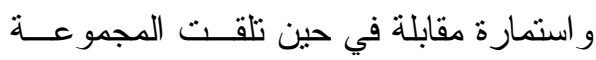
التجريبية أساليب التدريس الجديدة لمنهج علم

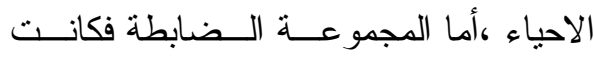

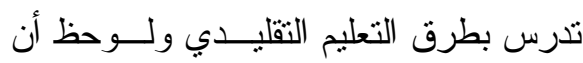
الطلاب في المجموعة التجريبية كانو ا أكتــر نشاطا لأنهم كانو ا يقومون بالأنشطة أنفـسهرح وكن ر أى معظم الطلاب أن الطريقة الجديدة حسنت الوعي البيئي .أن المــنهج الدراســـي فعال علي حد سواء في زيادة وعي الطلاب

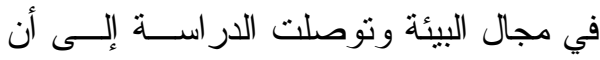

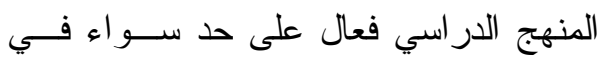
زيادة وعي الطلاب في مجال البيئة.

وهدفت دراسة , RajinderKaur

(ManpreetKaur "2009) على واقع الوعي البيئي لدى طلاب المرحلة

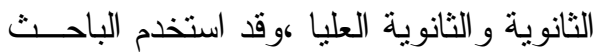
منهج المسح عن طريق العينـــة واســتخدام مقياس الوعي البيئي وذللك لقياس مدى وعي الطلاب عن تدهور البيئة وحمايتها وقد طبق الباحث الدر اسة على عينة من الطلبة عددها

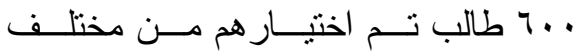

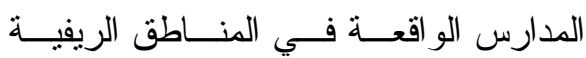
و الحضرية القريبة من حي باتيــالا و أخـــت لتهن عينة عشو ائية طبقية استخدمت لجمع العينـــة

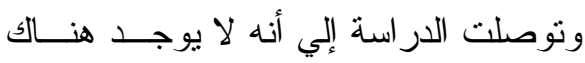

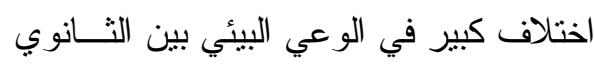

المصري في تتمية الوعي البيئي لاى المرأة

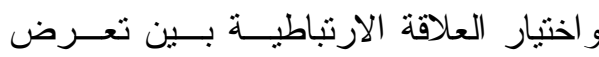

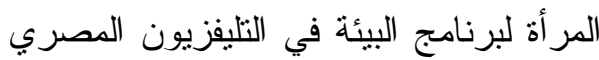

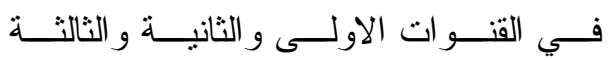
وحصولهما على معلومات عن البيئة بـصفة ولئة عامة، وذلك بهدف الوقوف على اعتمادهــا عاي التليفزيـــون كمــصدر للمعرفــة عــن المشكلات البيئية ،وقد اعتمدت الباحثة علــى كلى لـن نظرية الاعتماد على وسائل الاعلام، وتقرر أنه هناك علاقة اعتماد منبادلة بين الجمهور ووسائل الاعلام استخدمت الباحثــة مــنهج المسح على عينة عشو ائية تتكون مسن . IT

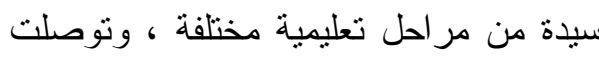
الدراسة إلى عدم وجود علاقـــة ذات دلالـــة إحصائية بين العمر والاعتماد الكمي علـى وجى التليفزيون للحصول علــى معلومسـات عـن لـن

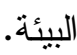
ثانيًا: الدراسات الأجنبية: لقد نتاولت بعض الدر اسات موضوع الوعي البيئـي مـنـ عدة زو ايا من هذه الدر اسات :

دراسة (Gulcan cetin and "2010) SedaHilalNisanci أساليب تدريس منهج الأحياء الجديــــ علي وعي طلبة الصف التاسع فــي مجـــال

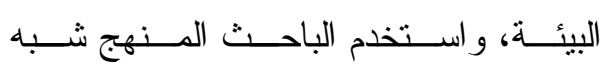
التجريبي، وقد تم استخدام الدر اسة باستخدام

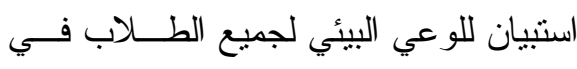


المحور الأول: الاطار المفاهيمي للتربية البيئية:

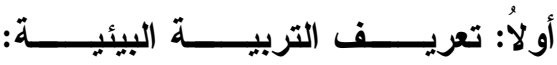

Environmental Education

لقد تعددت الآر اء حول مفهوم التربية

البيئية حيث تمنل التربية البيئية مفهوم تربوي البيان حديث نسبياً، نتج عن تفاعـل بـــين البيئـــة و التزبية وتأثنير كل منهما على الآخر ، وعليه

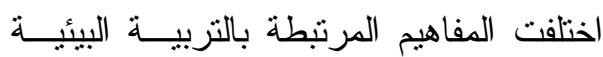
حيث تتعدد العملية التزبوية من حيث أهدافها ووسائلها، كما يرى البعض أن در اسة البيئة في حد ذاتها ضمان لتحقيــق تربيـــة بيئيـــة، و البعض الآخر يرى أن التربية البيئية أثمل و أعمق؛ حيث تطور مفهوم التزبيـــة البيئيـــة ليشمل النو احي الاقتصادية، و الاجتماعية؛ بعد

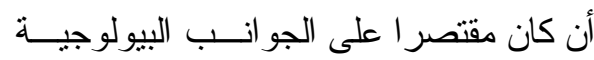
و الفيزيائية، و أصبحت النظم التربوية الحديثة تضع في مناهجها مو اضيع ذات مضامين لها

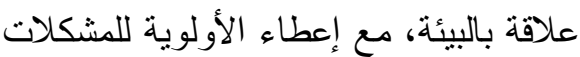

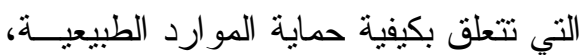

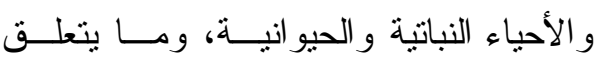
بها من موضوعات، كما قد توسع وتطــور

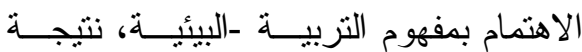

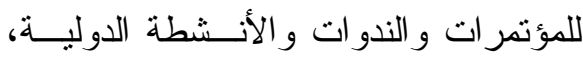
و الإفليمية و المحلية ( وهبي ، 2003 ، -53 ولكرل
و الثانوي العالي وأن هناك اختلافات كبيـــرة

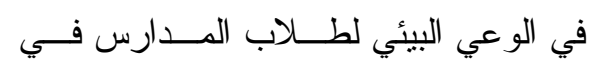

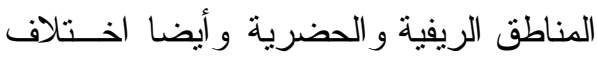
كبيرقي الوعي البيئي لدى الطـــلاب الــذين

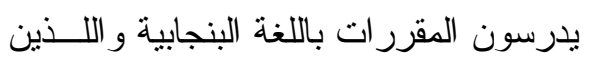
يدرسون المقررات باللغة الاتجليزية . بلانيه و عليه فإن دور التزبية البيئيــة فــي

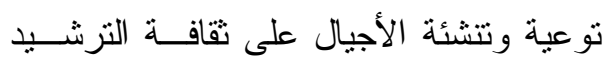

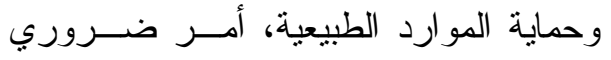
للحفاظ على الكثير من النعم التي أنعم الله بها

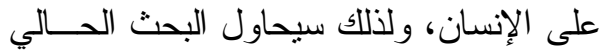

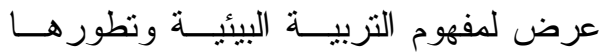

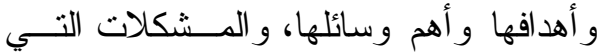

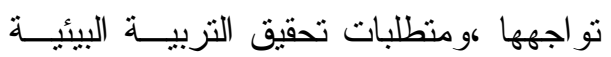
لدى طلاب المعاهد الثانوية الأزهرية.

وقد هدفت در اســـة ( Anne Scott

"Sandra"2007 ) إلى استكثاف خبر ات

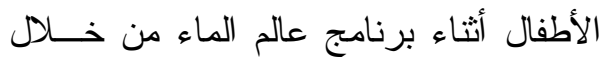

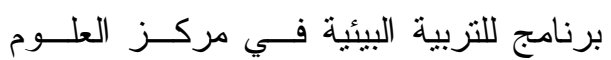
البحرية، وتكونت عينة الدراسة من ع أطفال

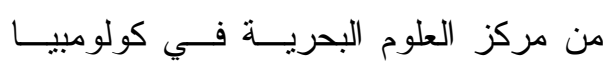

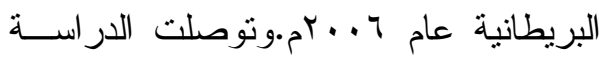

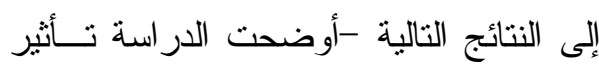

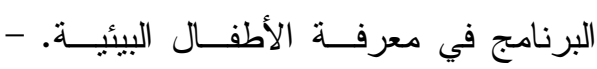
أوضحت الدر اسة أن المشاركة في الأنسشطة

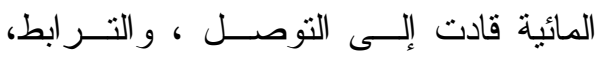
و الاهتمام بالبيئة البحرية ككل. 
ويمكن تعريفهــا بأنهــا "العمليــة

التعليمية التي تهدف إلى تتمية وعي بعني

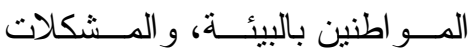

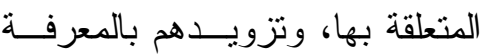

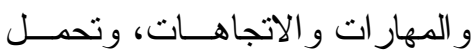

المسؤولية الفردية و الجماعية اتجـــاه

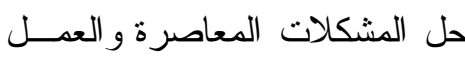

على منع ظهور مــشكلات بيائيــة

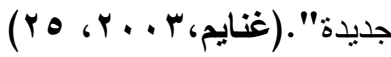

وقد عرفتها منظمة اليونسكو بأنها

التربية البيئية هي" :منهج نزبــوي

لتكوين الوعي البيئي؛ مــن خــلال

تزويد الفرد بالمعارف و المهـــار ات،

و القيم و الاتجاهات التي تتظم سلوكه،

وتمكنه مــن التفاعـل مــع بيئتــهـ

الاجتماعية و الطبيعية فيما بينهم؛ في

حمايتها وحل مشكلاتها."يؤكد هـــا

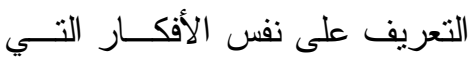

تتاولتها التعريفات السابقة، مع إضافة

لأهمية تفاعل الفــرد مـــع البيأســة

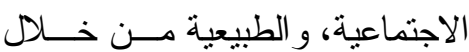

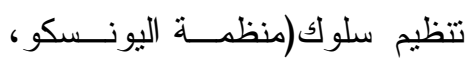
https://www.google.com.eg

( 1990

في حين عرفها الطائي(2010 ،-39

38) بأنها" : عملية تكوين المهار ات

و الاتجاهات و القيم اللازمسـة؛ لفهــ
و عليه يمكن عرض بعض التعريفات للتربية البيئية كما يلي: لمني عن

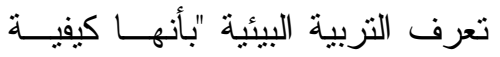
إدارة و تحسين العلاقات بين الإنسان و البيئة، مع القدرة علــى اســـتخدام التقنيات الحديثة وزيادة انتاجها مــع تجنب المخــاطر البيئيــة واتخــاذ القرارات البيئية العقلانية " (السعود،

.) 214 ، 2007

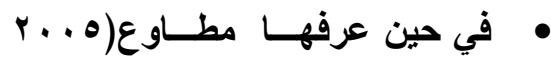

، ؛ 1 ) بأنها نمط من أنماط التربيـــة يهذف إلى تكوين جيل و اعي يهــتم بالبيئة وبالمشكلات المرتبطة بهــا، ولديه من المعارف و القدر ات العقلية،

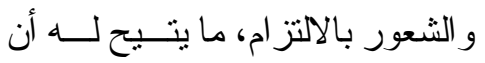
يمارس فرديا وجماعيا حل المشكلات القائمة و أن يحول بينها وبين العودة

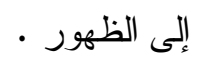

بينما تعرفهــا قــــ(28،2005 ).

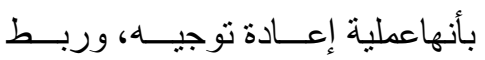
مختلف فروع المعرفة و الخبــرات التربوية، بما ييسر الإدر الك المتكامل للمشكلات، ويتيح القيــام بأعمــال عقلانية للمشاركة في مسؤولية تجنب المشكلات البيئية، و الارتقاء بنوعية البيئة . 
وجميع جو انب البيئة المختلفة الطبيعية

$$
\text { منها و الاجتماعية و الاقتصادية. }
$$

• تركز التربية البيئيــة علــى تجنـبـ

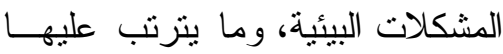

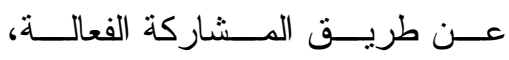

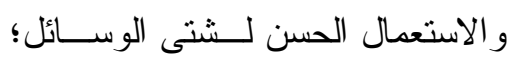

التي تساهم في الحفاظ علــى البيائــة

$$
\text { و الإنسان. }
$$

- التزبية البيئية، تسعى لتكوين الفرد في

جميع جو انبه وخصائصه المعرفيــة،

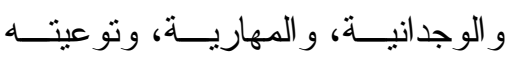

$$
\text { بأهمية المشاركة. }
$$

• أهمية التربية البيئية في تكوين الوعي

البيئي الذي يؤدي إلى المشاركة فــي

تحسين البيئة و الارتقاء بها ـ البودئ

ـ أن التزبية البيئية نمط مــن التزبيـــة

ينظم علاقة الإنسان بييئته الطبيعيــة

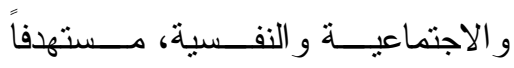

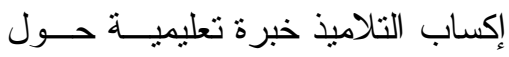

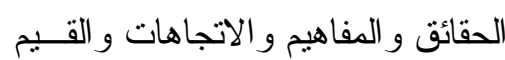

الخاصة بمــشكلات بيئيــة كــالتلوث

و الطاقة و استتز اف المو ارد الطبيعية .

ثانياً : التطور التاريخي للتربية البيئية

لقد أكدت الكثير من الأدبيـات التـي

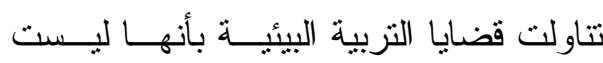

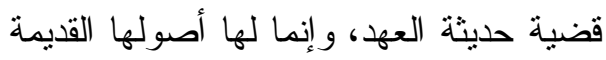

وتقدير العلاقات المعقدة التي تــربط

الإنسان وحضارته بمحطيه الحيوي،

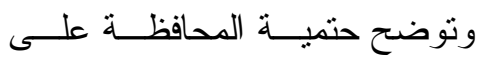

مصادر البيئــة، وضـــرورة حسـسن

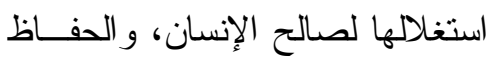

على حياته الكريمة، ورفع مـستوى

معيشته .

وعليه نزى الدر اســـة الحاليــة بــأن

التزبية البيئية هى "جهود تعليمية موجهــة أو مقصودة، نحو تعريف وتكـــوين الهــدركات

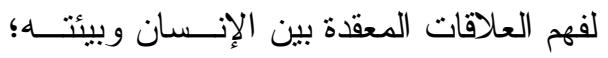

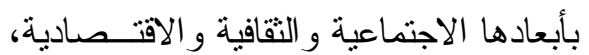
و البيولوجية و الطبيعية، حتى يكــون و اعيــا

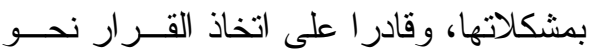
صياغتها، و الإسهام في حل مـشـاكلها؛ مـن أجل تحسين نوعية الحياة لنفـسه و لأســرته ولمحيطه وللعالم.

وبناء على ما تم تقديمه، يمكن القول

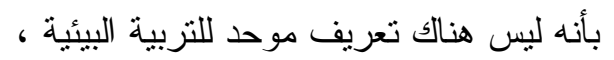
بل تتعدد التعريفات وتختلف من مجتمع لآخر حسب طبيعة المشكلات؛ التي تتطلب التركيز عليها في بر امج التعليم لكل بلد، إلا أنه يمكن لتهن

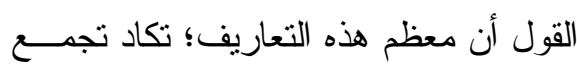
على أن التربية البيئة تركز على انى • أن التريبة البيئية جهد تعليمي وتربوي

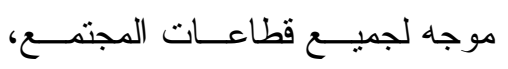


التي تتكون منها أنظمة الكائنات الحية وغير الحية، وإنما هو جزء لا يتجز أ من نظام الكون

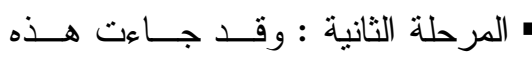

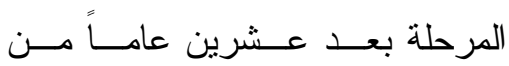

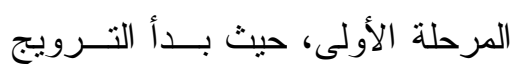

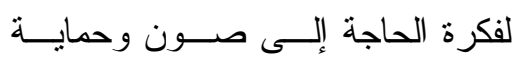
الموارد الطبيعية من قبل العديد مـن فـن

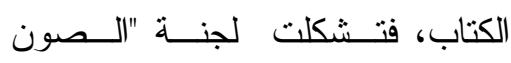
الوطنية" بالو لايات المتحدة الأمريكية، فعلى سبيل المثال لم تعد قيمة الغابات تتحصر في منتجاتها فحسب، و إنمــا

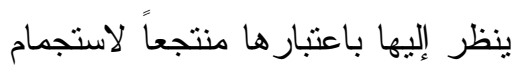

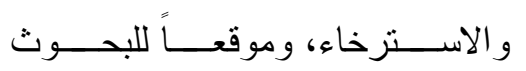
و الدر اسات في جميع الميادين.

• المرحلة الثالثة وهى مرحله الدراســـة

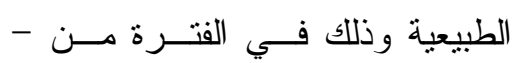
• 91 ام إلى بسو ام حيث ظهر تأثير

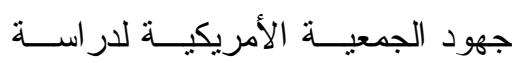
الطبيعة في تتمية الوعي لفهم الطبيعة

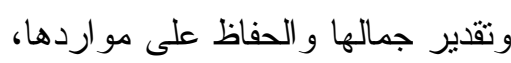

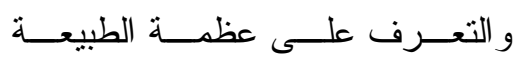
و أسر ار ها، كما ساهمت الجمعية فــي علي تصميم العديد من الأدوات و الوســائل

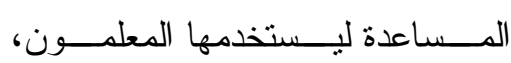
ودارسي الطبيعة كوسائل إرشــادية. المرحلة الرابعة وهي مرحلة التربية،
التي تمتد عبر التاريخ، في ثقافـات و أديــان

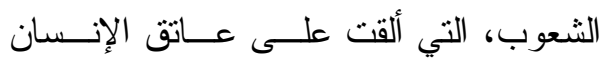
مسؤولية استثمار البيئة، و العناية بها و وعـدم الإندي

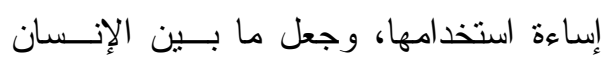

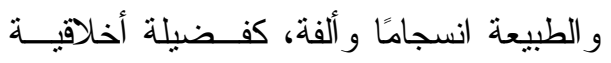
تعمل على إعداد الإنسان لمواجهة الحياة في ولهي

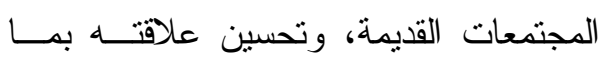
يحيط به، لتحقيق الحياة الكريمة له و لأجيــال من بعده ، و هي غاية أساسية للتربية البيئيـــة

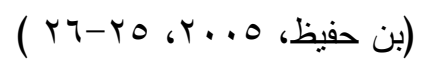
ونتيجة لتز ايد الاهتمام بالبيئة و انبثاق

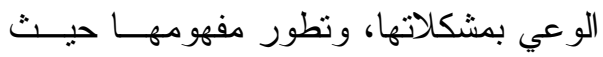

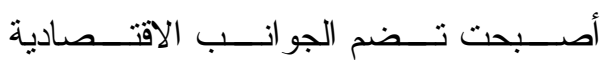

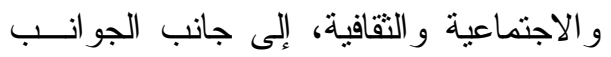

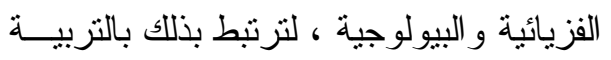

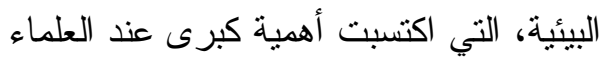
و الفلاسفة، خلال القــرنين الثـامن عـشـر و التاسع عشر ، و التي تــم إرســاء اســسها

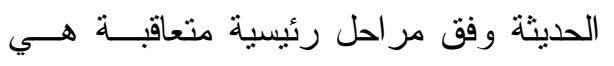

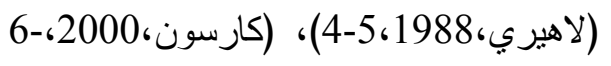

ـ المرحلة الأولية : وقد تمنلـــ هـــه

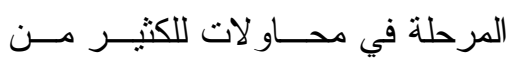

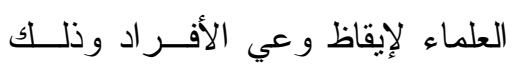

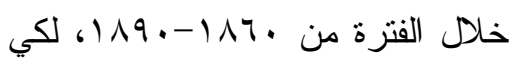
يدركوا أن الإنسان ليس كائناً وحيــداً

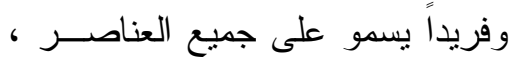


موضوع البيئة وحمايتها ودر استها و الاهتمام

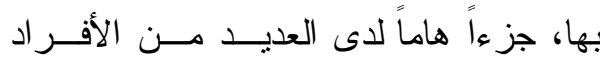

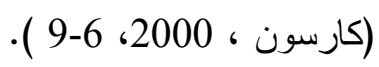

\section{بعض الجهود في مجال التربية البيئية}

لقد زاد الاعتراف بالدور الذي يمكن أن تلعبه التزبية البيئية، في حيــاة الإنـسـان وحماية البيئة وصيانتها بعد نزايد المشكلات

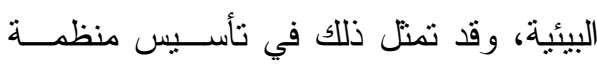

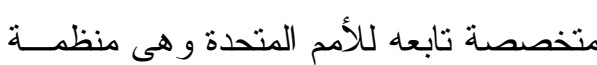

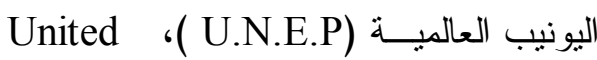
‘(Nations Environment) Program حيث هذه المنظمة بالتخطيط و التفعيل لبر امج

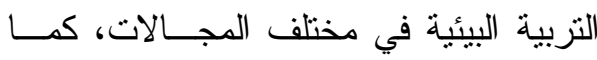

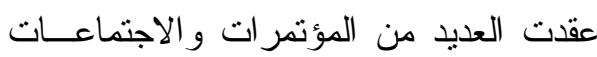
الدولية و الاقليمية و المحلية، منها الاجتمــاع العالمي للبيئة سنة 1970 بالتعاون مع منظمة ولهة ولها

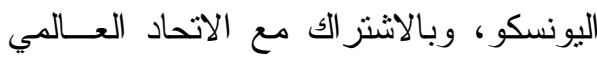

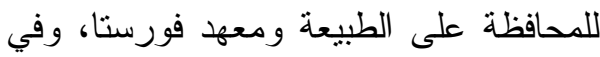
هذا الاجتماع تم تعريف التربية البيئية بأنها : عبارة عن معرفة القيم وتوضـــيح المفــاهيم التي تهدف إلى تتمية المهار ات اللازمة، لفهم وتقدير العلاقات التي تــربط بــين الاتــسـان وثقافته وبيئته الطبيعية، كما تعني أيضاً تنمبة الوعي بالقوانين المنظمة للحفاظ على البيئة،

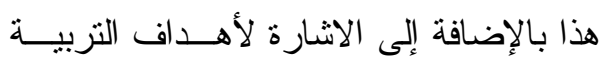

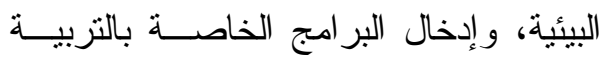
البيئية في التعليم (وهيبـي ، 2003، -138
حيث تم إنثاء الجمعية المدنية للصون عام 19TV التي أعطيت للعديد مـن الثباب فرصة للتعرف علــى قيمـــة الطبيعة، و القيام بالعديد من الأنشطة،

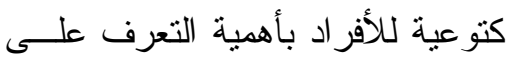
العلاقات المتبادلة، ومختلف التفاعلات التأثزية بيبهر وبين البيئة، وبذل العديد من الجهود فــي تــدريب المعلمــين ونشر مو اد تربوية تتعلق بالحفاظ على

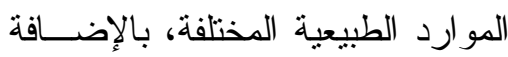
إلى المساهمة في تطوير المقــررات الار اسية ( لاهيري ، 1988 4-5 ) ومع تز ايد مخاطر المشكلات البيئيــة في العصر الحديث، بالإضافة إلى المشكلات التي تسبب فيها التطور العلمي و التكنولوجي ظهرت الحاجه الملحة لتنمية الوعي البيئي

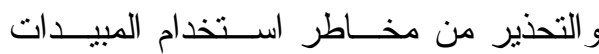
الكيماوية وغير ها علـى صنى صــة الإنسـسان و البيئةة، وكان من أبرز التأثنيرات في تتميـــة silent " الوعي البيئي، كتاب الربيع الصنامت الترني

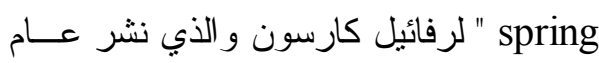

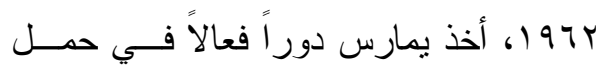
الحكومات على إحداث تغيرات جذرية فـي دئ دئ سياستها تجاه البيئة كما لعب دوراً حاسماً في لفي

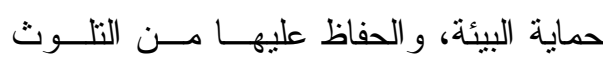
و الاندثار ، بل تعدى ذلك كله إلى المـسـاهمة ولثة

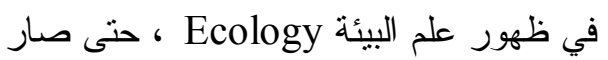


أثراً في اتجاه التفكير صوب الأخذ في معال

139 ). ليدرك مؤتمر روشليكون بسويسـرا

معالجة مشكلات البيئة، التي ترتكــز

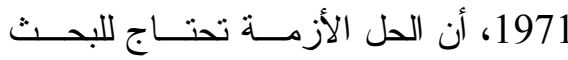

على الأبعـــاد الاجتماعيـــة و التقافيــــة

و العمل الدولي في موضوع التربية البيئيــة، الئ.

و الاقتصـادية، التي تحدد إليه الإنـسـان ولان

و إدخال المفاهيم البيئية في المواد الدراسـية

من توجهات ووسائل فكرية وتقنيــة ، الئه

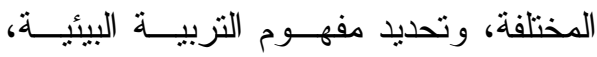

لفهم الجو انب البيولوجية و الفزيائيـــة، ولئ

و الأسس الاقتصادية التي يقوم عليه منــاهج

التي تشكل الأساس الطبيعــي للبيئــة

التربية البيئية في البر امج و المناهج الدراسية،

البشرية، واستخدامها على نحو أفضل

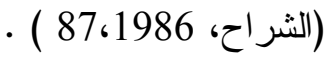

في تلبية احتياجاته، بفضل تفعيل دور

التربية البيئية وحمايتها، بعد أن وضع لئه

تصور و اضح وشامل للمخاطر للبيئة

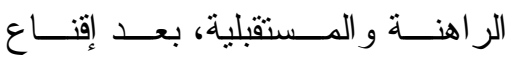

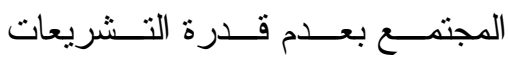

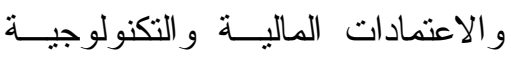

وحدها، على تحقيق الهدف المرجــ ولهو

منها في حماية البيئة ، وذللك لافتقار ها

إلى عملية تربوية نرتبط بهذه الأنشطة

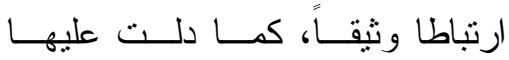

التوصية رقم (96) من هذا المؤتمر كابل

حيث كانت بمثابة الركيزة الأساســية

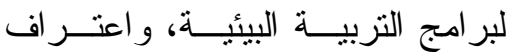

عالمي بأهميتها فــي حمايـــة البيئــة

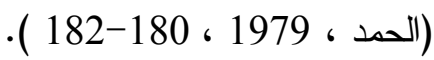

حيث احتوى هذا البرنامج الاهنمــام

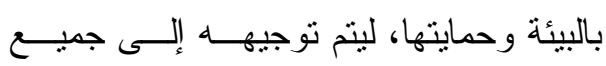

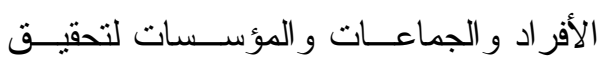

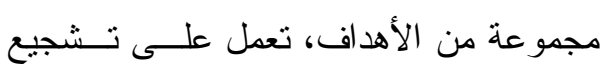

وقد اهتمت العديد من المؤتمرات بالتربيــة

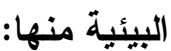

- مؤتثر روشــليكون بسويـسر ا عــام

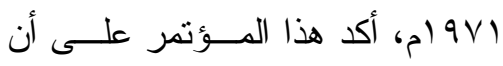

المشكلات البيئية مسألة عالمية، تحتاج

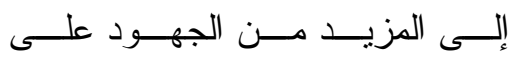

المستويات المختلفة للمساهمة في نشر

الوعي بها و العمل على حلها، حيـــث

بدأ إدخال المفاهيم البيئية في المنـــاهج

الدر اسية، وتوضيح مفهــوم التربيـــة

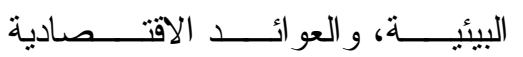

و الاجتماعية للتربية البيئية في التعليم

- مؤتمر الأمم المتحدة للتزبية البيئية في

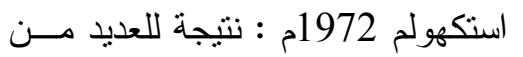

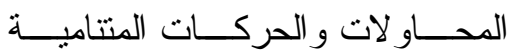

و المتصاعدة لأنصار البيئة وحمايتها،

انعقد أول مؤتمر رسمي للأمم المتحدة

في استكهولم في السويد في الفترة ما

بين 16-5 يونيو عام 1972، ناركــاً 
وتجنب المشكلات البيئية (السعود، 2004 ،

و عليه جاء ميناق بلغر اد بيو غـسلافيا

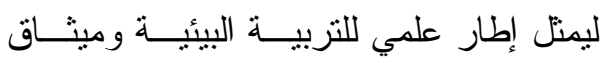
أخلاقي عالمي، وأساس لكل عمل مسـتقبلي

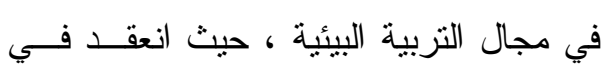
أكتوبر سنة 1975، بدعوة مــن البونـسكو

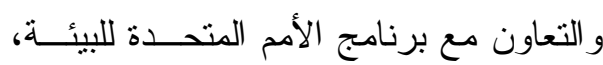

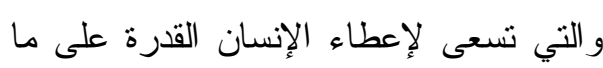

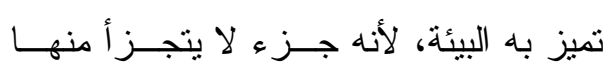

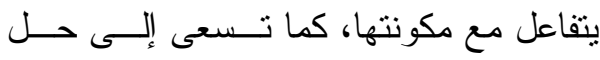
المشكلات البيئية عن طريق مساعدة الأفراد

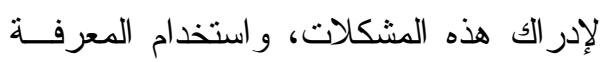
لتفسير الظواهر و اقتز اح حلول لمـشكلاتها، بتعميق الوعي الوطني للإنسان بأهمية البيئة

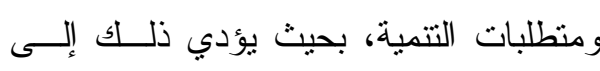

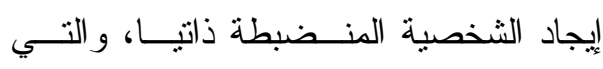

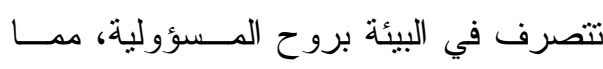
يتطلب ضرورة إدخال التزبية البيئيــة، فـي لئي

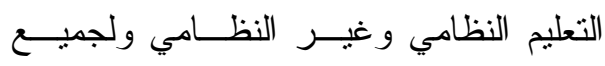

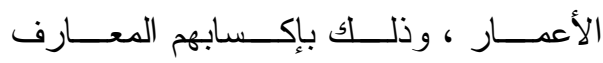

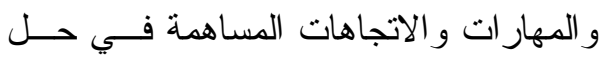

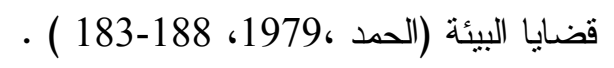
كما تم تحديد خصائص التزبية البيئية و التأكيد دور التربية في معالجة مـشكلات البيئة وحل المتجددة منها، و هي بهذا تحتــاج إلى شروط تخص مضمون التزبية، وتحليـلـل
تبــــادل الأفكــار و المعلومــات، و الخبــرات

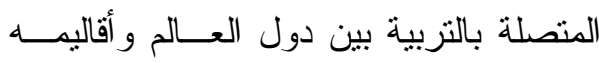
المختلفة، وتطوير نشاطات البحوث المؤديـــة إلى فهم أفضل لأهداف التربية البيئة وماداتها و أساليبها، وتتسيق هذه النشاطات ، و والعمـلـل

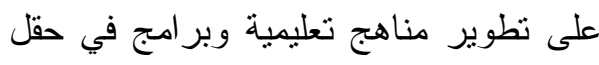
التربية البيئية وتقويمها، وتــدريب و وإعـادة

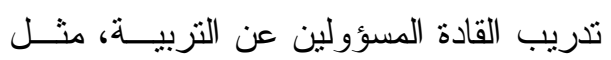

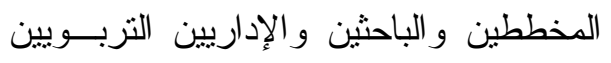

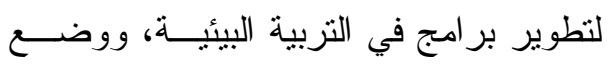
استر اتيجية خاصة للتتمية، وتحــسين البيئــة وتخفيض التزايد السكاني، و الحاجة الماســـة

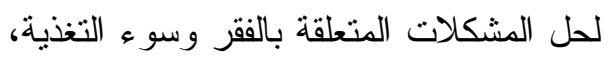

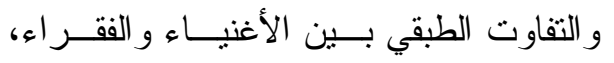

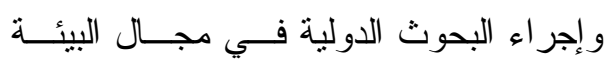
و القضاء على الأمية و الجهل بنــشر التعلــيم • البيئي

ميثاق بلغز اد بيوغـسلافيا كإطــار عملــي وأخلاقي للتربية البيئية 1975م :

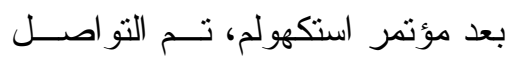

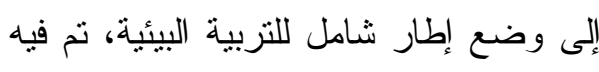

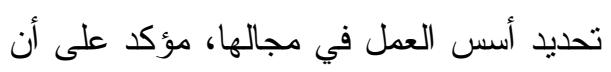

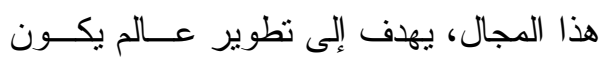
سكانه أكثر وعياً يكون سكانه أكثــر وعيــاً

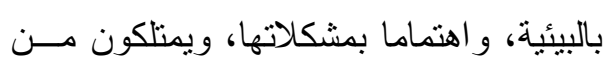
المعارف و المهار ات و المو اقـــ و والالتــز ام

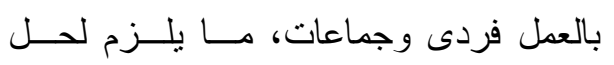


(الــــدمرداش ، 1988 ، 60-58)، )

كارسون ، 2000 ، 10 ) ) ( غنايم ، 2003

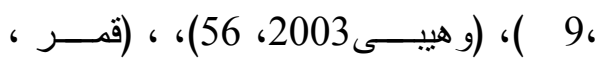

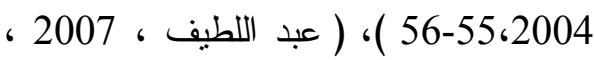

219-210-95 )، (مازن ، 2007 ، 2007 ( 13 ).

وسط عالم يتصف بــفات متقــدة،

تشكلت بتطور وسائل المو اصلات و أســاليب

الاتصالات بسرعة كبيرة، مع تز ايد الطلــبـ

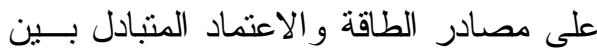

القوى المختلفة ، و التحالفات التي أدت إلــى

انتشار المشاكل، وعدم المساو اة و الصر اعات

التي تهدد بقاء الإنـسـان ، علــي المـستوى الإقليمي و الثقافي و البيئي .

فالتغيرات العميقة التي طر أت علـى هـ

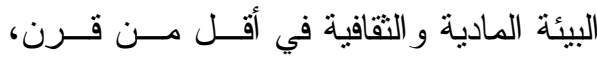

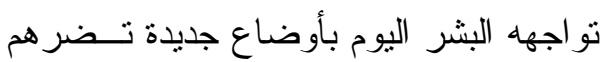
إلى الاستجابة باتخاذ مو اقف جديدة، و إتبــان

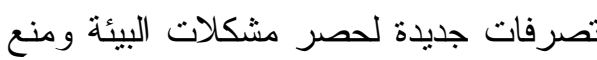

$$
\text { انتشار ها . }
$$

ولن يكون لهذا فائدة ومعنى، ما لــــ

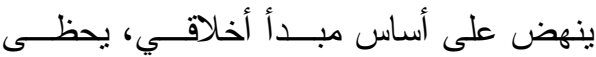

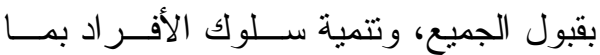

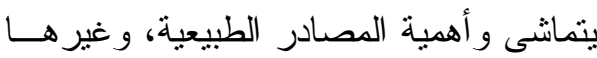

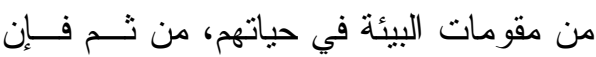

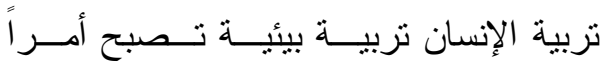

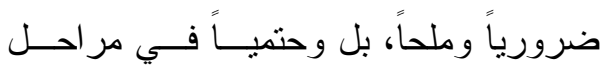

أساليبها وتقيبم الطــرق و الوســـائل الكفيلـــة بحلها، و إلى اثــتر الك الفـرد فــي وضـــع الاستر اتيجية، و الأنشطة الر امية إلى تئثر في

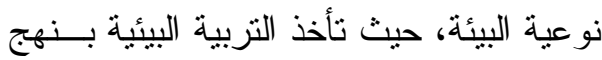
جامع لعدة فروع لعدة فروع علمية ، و التــي لئه

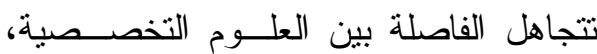

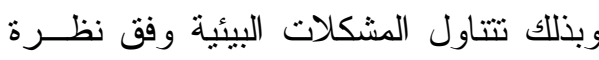
شمولية ، وطابع من الاستمر ار و التطلع إلى ولى المستقبل وما يتو افق مع التتمية المـستدامة،

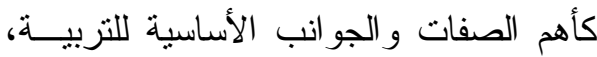
التي تستجيب لاحتياجات المجتمع .

أما المنتفعون في التزبية البيئية، فقد تم تحديدهم ضمن مجموعة التربية النظامية، وضم الأطفال قبل المدرسة وطلاب مر احـلـ لــل

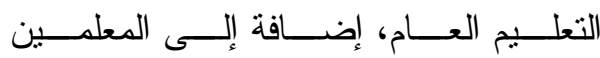
و الاختصاصين البيئين العاملين في التدريب أو إعادة التدريب، أما المجموعة الثانية فهي

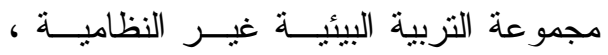

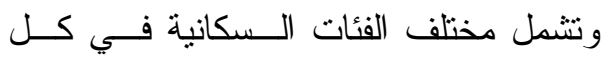
القطاعات كالثباب و الكبار و الأسرة و العمال ...، بما فيهم المسؤولين ممن يمكن أن يتأثر الناس بقر ارتهم (و هيبي، 2003،145-144 ) ثالثاً: أهمية التربية البيئية: تلعب التربية البيئية دورًا كبيرًا فـي القدرة على حل الكثير من المشكلات البيئية،

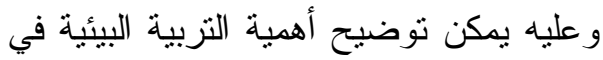

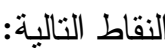




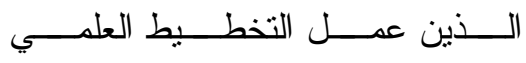

و التكنولوجي من أجلهم فعلى الأجيــال المقبلة إذن، أن تلتقي في أثناء تعليمها مما يجعلها على المحافظة على البيئة، لما يتضمن الإبقاء على الحياه بصورة

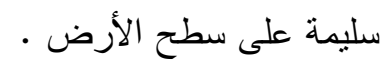

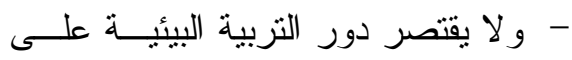
تدريس المعلومات و المعسـارف عـن بعض المـشكلات البيأيــة، كــالتلوث وتدهور المحيط الحيـوي واسـتنز اف الموارد، ولكنها تو اجه طموحاً أكتثـر من ذلك، يتمثل في إيقاظ الوعي الناقد

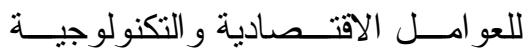
و الاجتماعية و الــــياسية و الأخلاقيــة، لـالية الكاملة في جذور المشكلات البيئيـة، وتتمية القيم الأخلاقية التي تحسن مسن طبيعة العلاقة بين الإنـسـان و البيئــة، و التي لا تتأتى إلا بالممارسة، ليتعلمو الئه مبادئ الإيكولوجيا في الو اقع. - تهتم التربية البيئة بجميع نواحي البيئة،

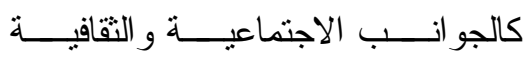
الاقتصادية و الجمالية، و لا تقتصر على ولى ولى

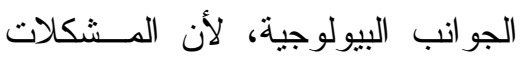
البيئة القائمة هي نتاج لأنشطة الإنسان

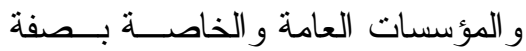
محلية وبطابع عالمي، لذا فإن التربيـــة البيئية تهدف إلى تعاون الجهود المحلية
لتبصر أجيال الحاضــر و المـستقبل

بإمكانية البيئة ودرجة تحملها ، لتطبيق الفكر الإنساني حتى يمكن إكسابهم اتجاهات موجهه تحمل مستوى تحمل البيئة لإنسان، و إعــداد

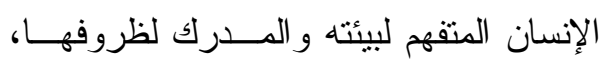
و الوعي لما يو اجهه من مشكلات وما يتهددها من أخطار، و القادر على المساهمة الإيجابية

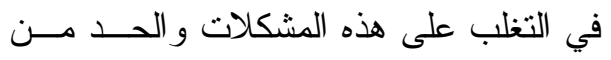

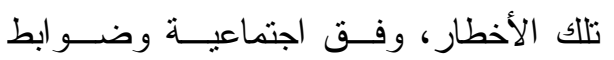
السلوك الذي يحسن ظروف هذه البيئة علــى نحو أفضل بوازع من داخل الإنسان، ويعمل

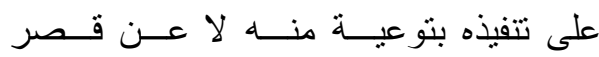
وكر اهية.

و علية يمكن توضيح أهميــة التربيـــة البيئية كما يلي: - تبصير الأفر اد بالقو انين و التـشريعات،

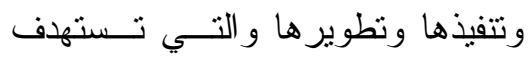

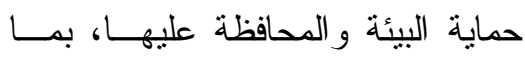
يحقق الأغراض المرجوة منها علـى لئى نحو أكثر فاعلية،

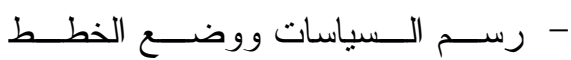

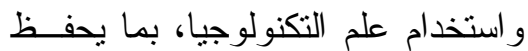
البيئة سلامتها ويحميها مـن التلـــ . لأنه من غير المعقول أن نخطط للإفادة

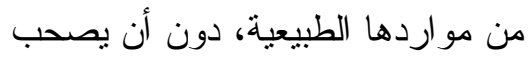

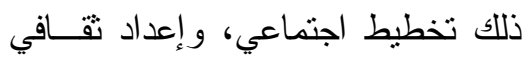

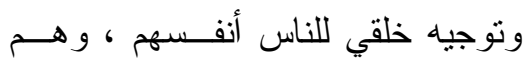


الوفاق بين الإنسان و البيئة، إلا بمساعده

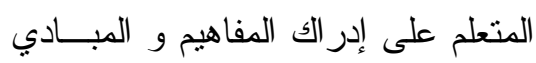

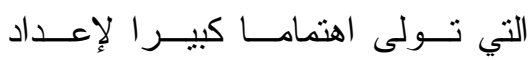
المو اطنين الواعين لمــشكلات البيئــة،

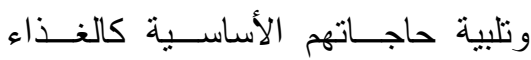
و الرعاية الصحية، و الإفادة من النفيات ومحاربة التبزير ، و إعادة بناء البيئة من والئ هن

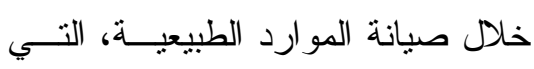

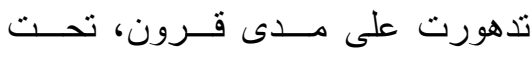
تأثثير ات الجو انب وتغليبها علــى القــيم والأخلاق البيئية .

- مساعدة المتعلم علـى إدر الك بعـض المفاهيم و المبادئ، التي تولى اهتمامسـا كبير اً لإعــداد المـــواطنين المنتبهـين للمشكلات البيئية حيث، تقوم وتؤسس على عدة مفاهيم يرتكز عليها النظـــام التربوي، كالوجود و المعرفة و الطبيعة الإنسانية وتتضمن در اسة العلاقة بـين

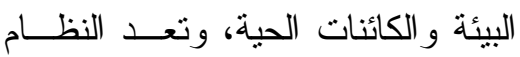
البيئي بمختلف عو امل التلوث و الطاقة و الإسكان و أشكلها إلى جانب النــــو

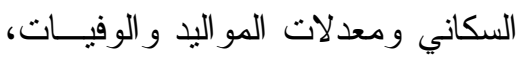

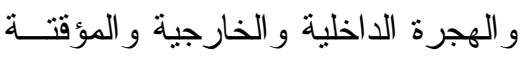
و المؤسسية وتوزيعهم، وأثز ذلك على ولى ولى ولى

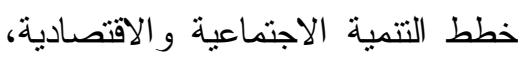

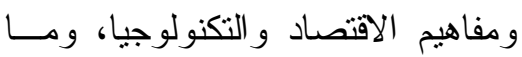

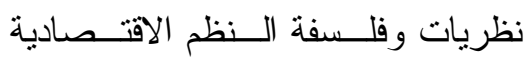

و العالمية، و التصدي للمشكلات البيئية

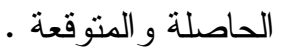
- تقوم بتعديل مواقف الأفراد من البيئة، وترسيخ طرق ومناهج فكرية ومعارف جديدة ، وتقييم الأثر البيئي، و المحافظة

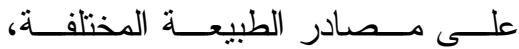
و إكساب سلوك إيجابي اتجاه المشكلات ، التي تتجم عن تفاعل الإنسان معهـــا مما يطلب و عياً بيئياً نربوياً، لذك يجب الإنبان دعث

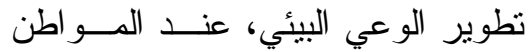
و الطالب وتحكمه وترشيده .

تتشئة الفرد الو اعي بيئيــا و المنــضطبط دائما ، للإحساس بالمسؤولية الأخلاقية دون رقابـــة خارجيــة اتجـــاه البيئــة، وتطبيق المعارف إلى سلوك عملي عن قناعة نابعة من ذات الفرد، و الابتعـاد عن الأنانية وإحداث الخلل في مكونات دنات داتهات البيئة ونظامها .التي تعد الانسان جـزء البهـ متكامل من هذا النظام، الذى لا يسنطيع الانفصـال عنـــة، إلــى جانـــب البيئسـة

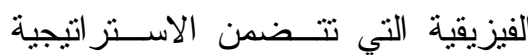

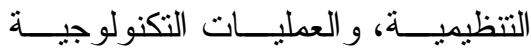
و النظريــات الاجتماعبـــة و الـــسياسية و الإداريـــة و التـــــريعية، و التعليميـــة الخاصة بالتزبية البيئية لتطوير النظــام التزبوي وتحـسـين وترشــيد التربيــة النظامية خاصة. لأنه لا سبيل لإعـادة 
- تتتاول القضايا الكبرى من وجهة نظـــر

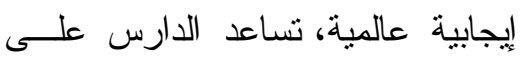
تكوين رؤية للظروف البيئة في مناطق

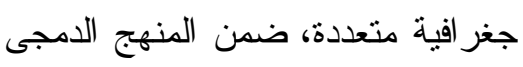
الذى يجمع بين عدة أنظمة، بغية تدعيم

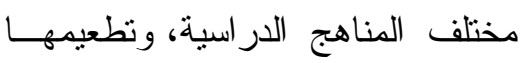
بالتزبية بصورة وظيفية هادفة بـدون

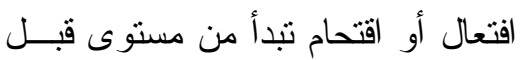

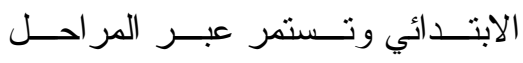

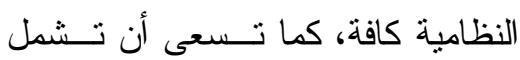

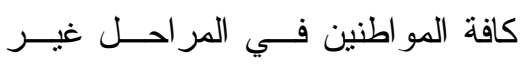
النظامية، وتفعيل دور هم فـــي حمايــة البيئة و العمل على تحسينها، و المشاركة ولهي

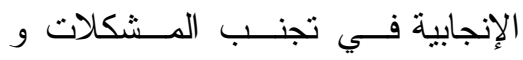

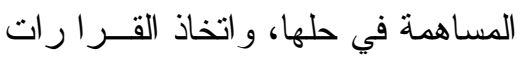

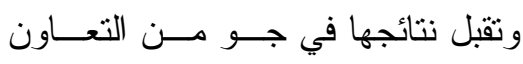

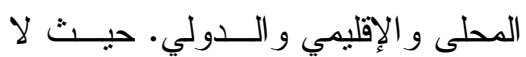
تتعارض هذه الأسس أو التوجهات في فلسفة التربية البيئية، مع الفلسفة الندية تنادي بعلاقة انسجام الإنسان بالطبيعة،

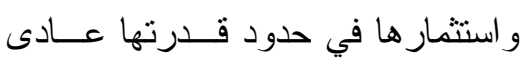
التجدد و العطاء، إلا أنها لا تتفق مــع الفلسفة الحتمية، بأن على الإنـسـان أن يخضع للطبيعة لأنها أقوى منه، كما أن الن الن ان

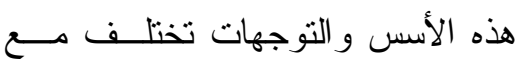
الفلسفة الإمكانية، التي تـــؤمن بقــدرة

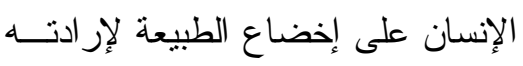

و الإنتاج و وعو امله، و التكنولوجيا و أثز ها

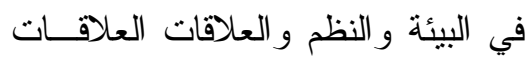

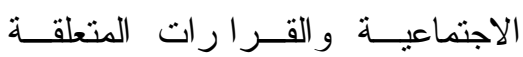
بحماية البيئة، وما تتضنهنه من قوانين

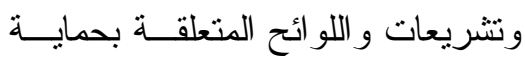
و المحافظة عليها. - در اسة أساليب اتخاذ القر ارات و أثرهـــ على البيئة و در اسة مـسشكلات البيئــة

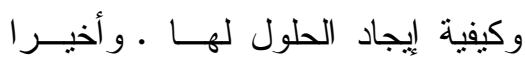
مفاهيم الأخلاقيات و السلوك البيئي، وما ولئ تتضمنه من شرح المبــادئ و القـيم الأخلاقية، و انماط الــسلوك الإيجــابي الو اجب إتباعها فى التعامل مع مكونات ولاهيل النظام البيئي، هذه المفاهيم التي ترنكز على عدة أبعاد، تتظر من خلال التربية البيئية الى البيئة في كليتها الطبيعيــة، التي وجدت عليها و التي هي من صنع

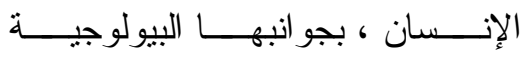

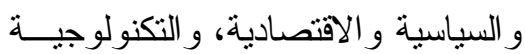

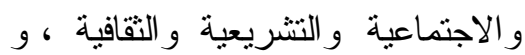

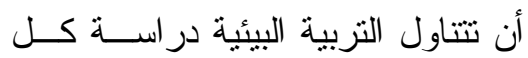
قضايا التتمية من منظور بيئي، يحرس لتسر لئه على استثمار البيئة دون إهدار ثرو اتها

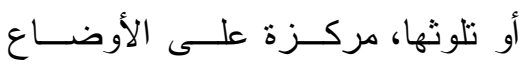

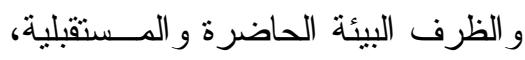

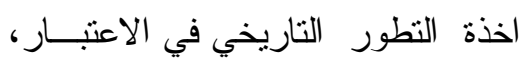
كبعد زمنى ومختلف الفروق الإقليمية. 
مشكلات جديدة ـ وأن التزبية البيئية يجب أن تهدف إلى إيجاد الاتجاهات السلوكية الواعية

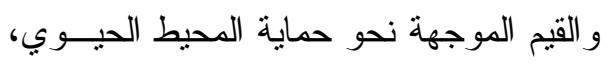

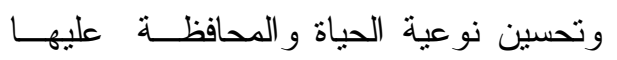

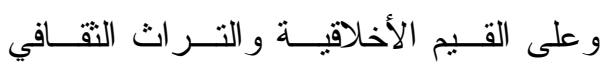

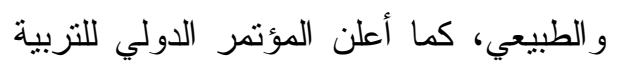
البيئية في تنليبي ( بارك، 1987 ،10-11 ) وقد حدد وليم ســتاب الأهـــاف الرئيسـية

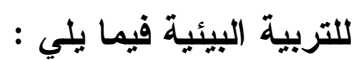
تساعد الأفراد على اكتـساب فهــ

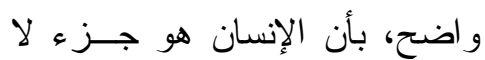
يتجز أ من نظام يتألف من الإنسـسان و التقافة البيو فيزيقية . أن الإنسان له القدرة علــى تغيــر العلاقات في هذا النظام. • أن الإنسان له القدرة على تغيير في

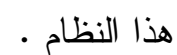

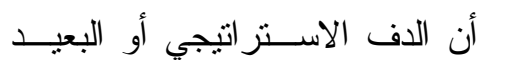

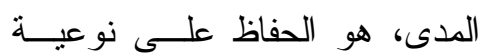
النظام الذي يتفاعل فيه الإنسان، من خلال ثقافته مع البيئة البيو فيزيقية

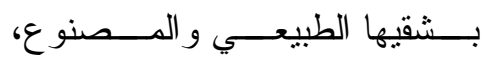

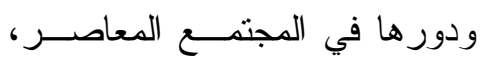

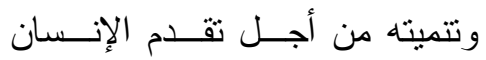
ورفاهيته .
، لتشكل بذلك إطـــار اً فلــسفياً عامــاً للتربية البيئية، الطبيعية و الاقتـ لصادية

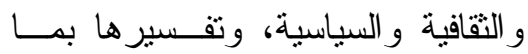

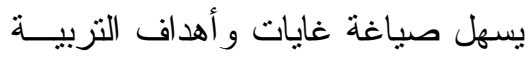
البيئية وتوجيهها لـ رابعاً : أهداف التربية البيئية لقد ارتبطت صباغة أهداف التربيــة البيئية، بالعديد من المشكلات البيئية المحليـــة

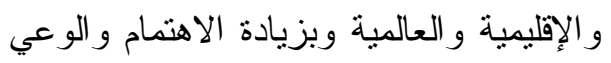

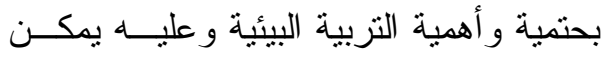
تحديد أهداف التربية البيئية في الآتي: - الأهد|ف العامة :

تتميز هذه الأهـــداف بأنهــا شــاملة و عامة، إلا أنها تحدد سلسلة من الاتجاهــات

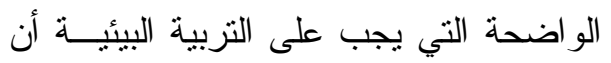

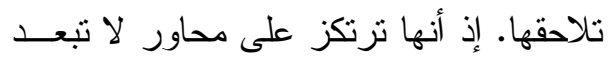

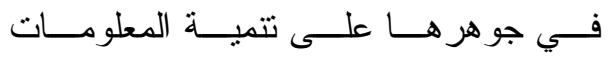
و الاتجاهات وغرس القيم و إكساب المهار ات، إلا أنها تحتاج إلى مهار ات تربوية ودر اسات وبحوث مستقفضة ومتعددة لتحقيقها، إلا أنها تحتاج إلى تطوير عالم يكون ســكانه أكتــر

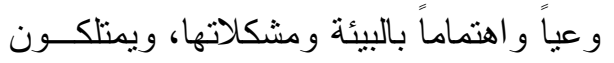
مــن المعــارف و المهــار ات و الاتجاهــات و الدوافع و الالتز ام بالعمل فر ادى وجماعات،

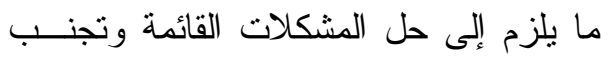
حدوث مشكلات القائمسـة وتجنــب حــدوث 
الحاضر و المستقبل، ولن يكون ذللك إلا بتتمية

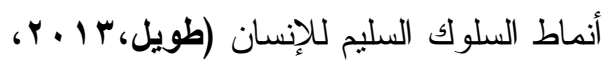

( ( v)

أ- الأهداف التربوية السلوكية :

تعتبر الأهــداف العامــة و الخاصـــة

(الفرعية ) للتزبية البيئية، مصدر لاشتـنياق

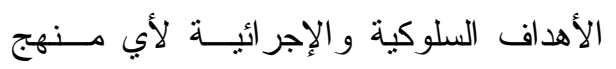

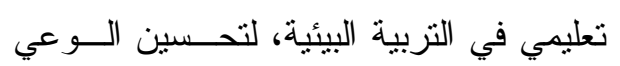

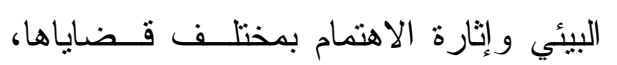

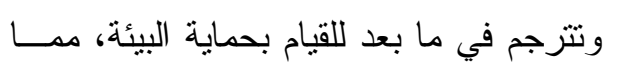

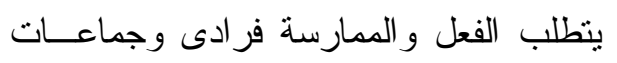

في التعليم النظامي وغير النظــامي، و التــي وني

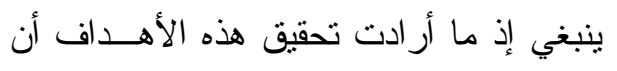

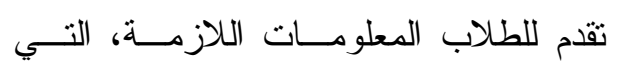

تساعدهم على فهم بيئتهم البيوفزيقية من جهة وأن تكسبهم اتجاهات و اهتمامات موجهه نحو لتهن

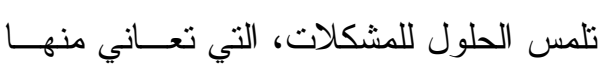
منجه أخرى وذا مـــا يعبــر عنـــه أحيانــاً بخصائص المـتـعلم المعرفيــة و الوجدانيـــة و المهارية (طويل، 2013، 71). و الأهداف التربوية السلوكية تتضمن:

• البعد المعرفي: وذللك بتوفير المعلومات

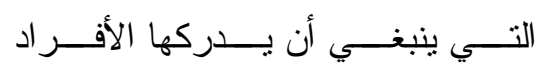

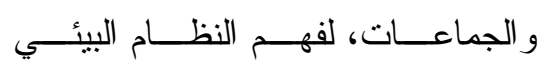

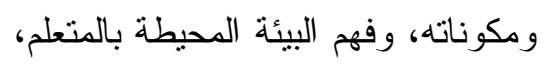

$$
\begin{aligned}
& \text { • الفهم العميق و الثشامل للمـشكلات } \\
& \text { البيئية التي تو اجــه الإنـسان فـي ولئي } \\
& \text { الوقت الحاضر }
\end{aligned}
$$

• المساهمة في حل هذه المـشكلات بمشاركة جميع الأفر اد و الجماعات. إكساب المهارات اللازمـــة لحـل المشكلات، ومهــار ات الاتـصال ومهار ات النقل و التعبير اللازم لحل ومهات الاتل

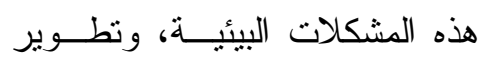

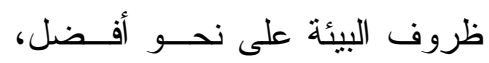
يهدف لتكوين الاتجاهات المناسـبة

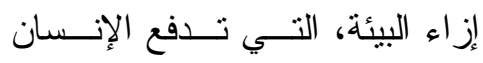
بو ازع منه إلى المشاركة في حسل لــل المشكلات البيأيــة ـ ( الــــمرداش فئس

(74-72، 1988،

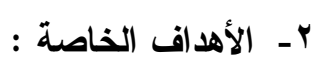

لقد تم تزجمة الأهداف العامة، التـي

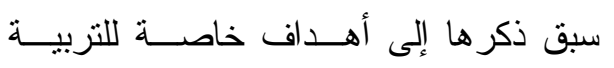

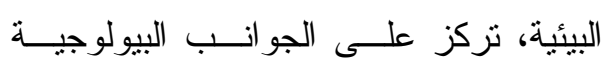
و الطبيعية، وما يرتبط بها من مو ارد متجددة وغير متجددة ، ومختلف المـشاكل البيئيــة مونة

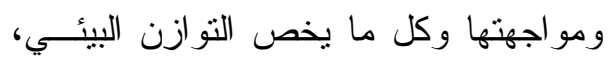
مؤكد على فكرة التكامل للإنسان مع بيئتــه

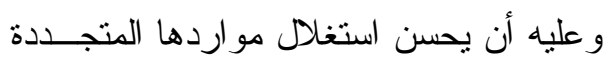

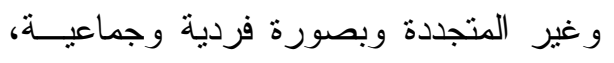

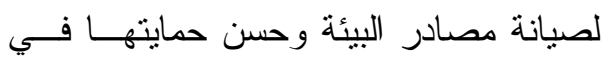


بالمقترحات و التوصيات للتقليــل مــن المخاطر البيئيّة .

هاحية الخُلقيّة: يعود ذلك للإنسان نفسه ومستوى استعداده بأن يكون فرداً نافعاً في المجتمع، ويحرص على مصلحته،

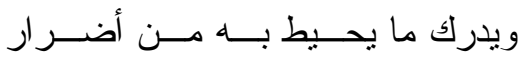

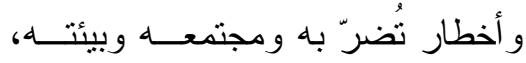

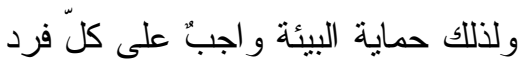

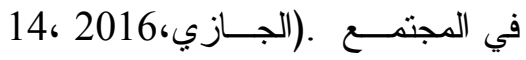
https://mawdoo3.com (نوفمبر

\section{سادسًا: مداخل التربية البيئية}

ا - مدخل الوحدات الدراسية units :

يعتمد هذا الدخل علي تضمين وحــدة دراسية أو فصل دراسـي(chapter) فـي وني إحدى المواد الدراسية، أو توجيه مناهج مادة

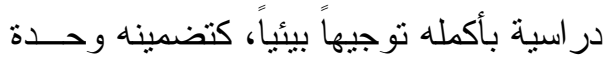
البيئة في كتاب الأحياء، و الانفجار الـسكاني بـائي في كتاب الجغر افية . وتخصيص فصل عن

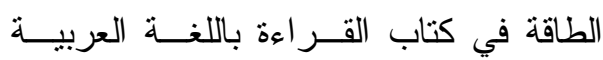

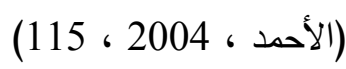

r- المدخل الاندماجي : ويتم تـضمين البعد البيئي في المـــواد الدراســية البـانية النقليدية بإدخال معلومات بيئيــة أو لئي ربط المحتوي بقضايا بيئية مناسبة

$$
\text { (صباريني ، 1993، 99 }
$$

وكل ما تحويه من موارد وما تتعرض من لله من مشكلات مل ناله من

• البعد المهارى: ويشمل مهار ات الفنبـــة و اللغوية المناسبة، و التخطــيط البيئـي و التز ابط بــين العو امــل و المــشكلات البيئية، وتقـــويم معــايير الاســتخدام و التأكد من صدق المعلومات و البحــث عن مصادر ها وكيفية استخدامها. • البعد الانفعـالي: (الوجــــي): الــــي يوجب التزبية البيئية أن نطور المو اقف الفع

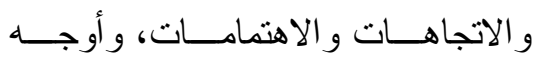
التقدير وبالتفاعل بين البيئــة وتــذوق واهو جمالها و الرضي بتو ازنهــا، و الــشعور بالحاجة للتحــسين العلاقــات البيئيــة.

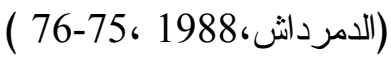
خامسًا: مبادئ التّربية البيئيّة

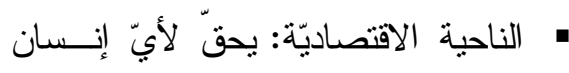

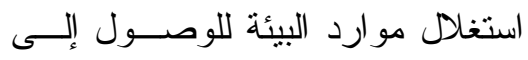

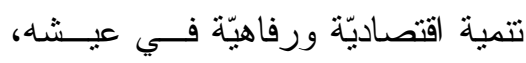
ولكن يجب أن يكون هــذا الاســتغلال منظماً وغيــر عـشـو ائيّ، ومر اعيــاً النو احي البيئيّة. • الناحية العلميّة: أي اعتمــاد الجانــب العلميّ من أجل التعامل مـــع البيائــة؛ سو اء كان ذلك بالتخطيط العلىـيّ، أو لئي 
• التزبيــة البيئيــة تـسعى لتوضــــح

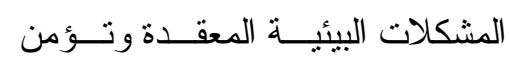

تضافر أنواع المعرفـــة الــلا زمـــــة

$$
\text { لتقسير ها. }
$$

ه التزبية البيئية تأخذ بمنهج جامع لعــدة

فروع علمية في تتاول مشكلات البيئة.

• التزبية البيئية تحرص على أن تتفـتـح

على المجنمع المحلي إيماناً منها بـأن

الأفر اد لا يولون اهتمامهم لنوعية البيئة

و لا يتحركون لصيانتها أو لتحــسينها

بجدية و إصرار إلا في غمار الحيــاة

اليو مية لمجتمعهم.

ـ التزبية البيئية تسعى بحكـــم طبيعتهــــا

ووظيفتها لتوجه شتى قطاعات المجتمع إلى بذل جهو دها بما تملك

• من وسائل لفهم البيئة ونرشيد إدارتها

وتحسينها، وهي بذللك تأخـــذ بفكــرة

التربية الثاملة المــستـديمة و المتاحـــة

$$
\text { لجميع فئات الناس. }
$$

• التربية البيئية تتميز بطابع الاستمرارية

و التطلــع ع إلــى المـستقبل (الحمــــ،

$$
\text { صباريني، } 1997 \text { (76، }
$$

إن التزبية البيئية تعد استجابة للأزمة

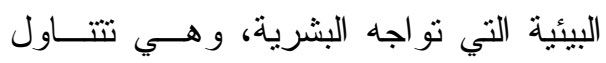

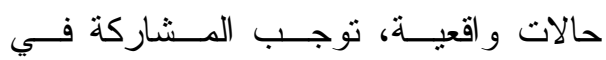

دارستها، وتأخـــذ أهـــــاف التربيـــة البيئيـــة r- المدخل المـستقل : ويتمثتل فــي

بر امج در اســية متكاملـــة للتربيــة

البيئية كمنهاج در اسي مستقل، ورذا

يناسب مرحلــة ريـــاض الأطفــال

و الصفوف الأساسية الأولي . وهذا

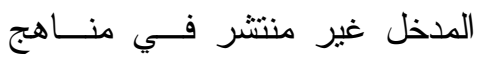

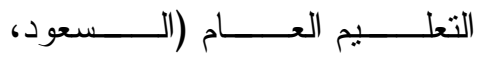

. $(223 ، 2004$

ــ المدخل الاجنماعي : ومن أهــاف

هذا المدخل إيراز العلاقة بين العلم

و التكنولوجيا و المجتمع و البيئة حيث

يتيح الفرصة للمتعلمــين التــدريب

علي اتخاذ القرار ات بالنسبة للحياة

اليومية ومستقبل المجتمع ·

0ـ المدخل المفاهيمي: حيـــث بــنظم

محتوي المنهج حول مفاهيم عامــة

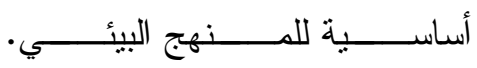

http://salahagag.jeeran.c

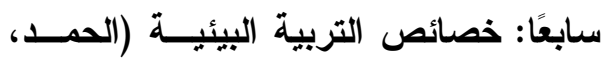

صباريني، 1997 (76،

تتسم خصائص التزبية البيئية بجملـــة

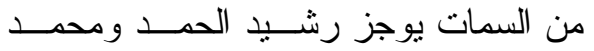
صباريني أبرز ها بما يلي:

ـ التزبية البيئية تتجه عــادة إلـى حـلـ

مشكلات محدودة للبيئة البشرية عـن

طريق مساعدة النــاس علــى هـــذه 
لدوره الفعال في إبر از مبادئ و أهداف و مز ايا المحافظة على مكونات البيئة ومختل التدابير الوقائية التي يتعين اتخاذها من أجل المحافظة

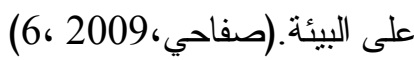
وبالتالي فإن دور الطلاب في المعاهد الاز هرية الثانوية في المحافظة على البيئة،

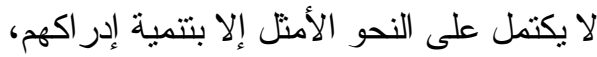
وتوجيه سلوكهم، و اكتسابهم المفاهيم البيائيــة

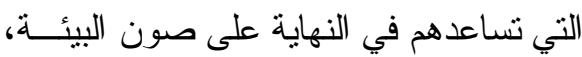

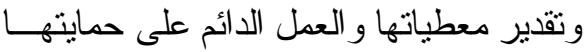
من كل ما يحدق بها من مخاطر ، و هذه هـــي ولهي فلسفة النزبية البيئية وسائل حماية البيئة: عدم الإسر اف في استخدام الماء.

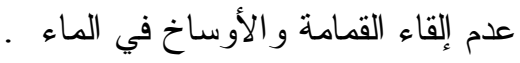
الاعتدال في استخدام المواد الكيميائية؛

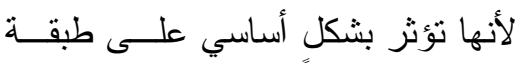
الأوزون الابتعاد عن حرق العو ادم التـــي تـــتج

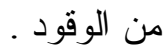

عمل دور ات وندوات لتوعية الأفـــراد

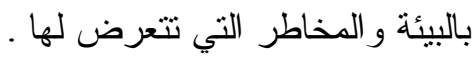
الحفاظ على صحة التزبة، وذلك مسن خلال ريّها أو تجنب رمسي الأوســاخ

$$
\text { و الفضلات فيها . }
$$

المعرفية بالمنحى التداخلي. و التربية البيائـــة

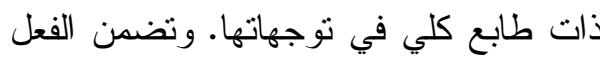

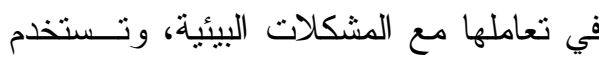

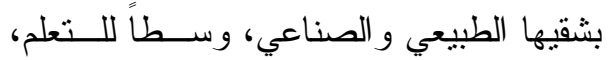
وتبحث عن البدائل فـي دراســة الحــالات البيئية. وتسعى إلى تنبي المدخل القيمي الذي

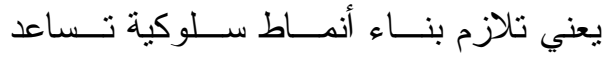
بالمحافظة على البيئة. وتهتم بأسس الاختيار بين بدائل الحالات البيئية. وتهـــف التربيــة البيئة إلى تطوير مهار ات حـل المـشكلات

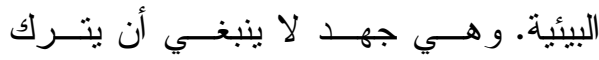

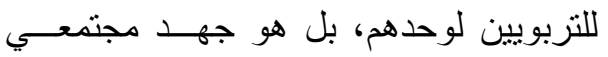

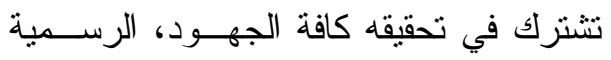

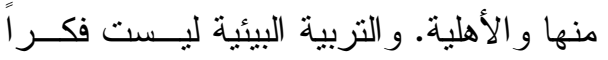

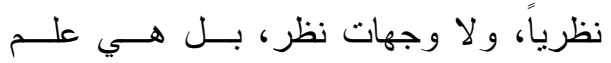
تطبيقي يتجلى بالفعل و الممارسة (عريبـات ولهات (14،2009، دور التربية البيئية في حماية البيئة: التحسن المنشود للمؤشــــرات البيئيـــة و التحكم فـي تــــهور الهـــوارد الطبيعيــة، و الإدماج الفعلي للبعد البيئي في المخططــات و الاستر اتيجيات الاقتصادية للبلاد. وبهذا نستتنج أن حماية البيئة تتطلــبـ

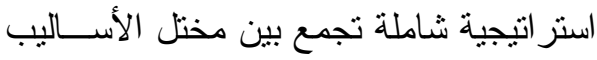
مادامت حمايتها مسؤولية الجميع، ولهذا تأني أهمية النزبية البيئية ، كأسلوب جديد لمو اجهة الأخطار البيئية لا يمكن الاستغناء عنه، نظر الئه 
تتعرضون لها مثل مــشكلة الحفــاظ علـىى المصادر الطبيعية.

المئسور الثـاني: المشككلات الـتي تعـوق التربيـة

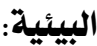

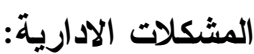

لا تشترك إدارة المعهد فــي تتظـيم

ندو ات حول التربية البيئية

• ضعف المشاركة بين إدارة المعهد في

التو عية بقضايا البيئة ومشكلاتها

• ضعف قضايا التربية البيئية ومشكلاتها

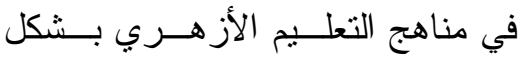

مناسب

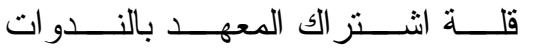

و المؤتمر ات التي تدعم قضايا التزبيـــة

البيئية

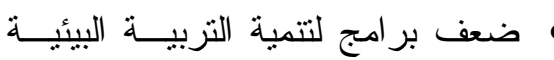

لطلاب المعهد الثانوي الأزهري لزي لرجه

• ضعف التنسيق بــين القـائمين علــى

العملية التعليمية ومؤسسات المجتمــع

الأخرى في مجال نشر الوعي البيئي

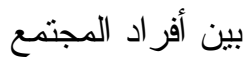

ضعف إجر اء المزيد مــن الدراســات

حول قضايا البيئة و الوعي بأبعادها

• ضعف وسائل الإعلام في مجال رفـع

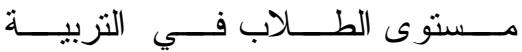

البيئية
• إعادة تدوير النفايات بدلاً من رميهــا،

وتساعد نلك الطريقة على تحسين البيئة

و الحفاظ عليها .

• تجنب استخدام المبيدات الحشرية؛ لأنها

تؤثر بشكل أساســي علــى التزبـــة،

و استبدالها بالمبيدات الطبيعية .

• سنّ قو انين و أعر اف تتصنّ على الحفاظ

على البيئة، وذلك من خلال معاقبة من ون

$$
\text { يخربون البيئة . }
$$

- عدم الاعتداء على حقوق الآخرين في

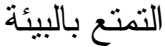

• ز زيادة الوعي البيأــي لــدى الأفــر اد،

وضرورة تعريفهم في أهمية البيئة .

"الاهتمام بالبيئــة مــن قبــلـ الهيئــات

الحكومية المختلفــة مثــلــ البلــديات

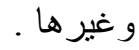

- إعطاء العمال الذين يعملون في مجال

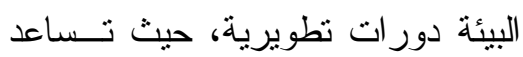

بدور ها على زيادة وعيهم حول البيئة .

و عموماً يمكن القول: أن هذا الفــصل

تتاول استراتيجية التربية البيئية كنسق جزئي

يؤدي وظائف و أدوار هذه الدراسة، وتهدف

التزبية البيئية إلى تربية الطلاب تربية بيئيــة

تجعلهم قادرين على التفاعل مع بيئتهم، وذلك

لأنهم مطالبين في المستقبل باتخاذ قــر ارات

تنؤثر علي بيئتهم، وتصديهم للمشكلات التـي 


$$
\begin{aligned}
& \text { لا يسهم معلمي الأنشطة المدرسية في }
\end{aligned}
$$

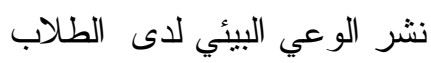

$$
\begin{aligned}
& \text { لا يصمم المعلم بعض الأنـشطة الــلا } \\
& \text { صــفية لعــرض المــشكلات البيئيــة } \\
& \text { للتعريف بأهمية الموارد البيئية وطرق } \\
& \text { ترشيدها }
\end{aligned}
$$

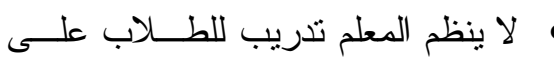

$$
\begin{aligned}
& \text { مناقشة الوعي البيئي } \\
& \text { لا يستثمر المعلمون بعض الــسلوكيات } \\
& \text { اليومية لدى الطلاب لتوجيهـم لترشيد } \\
& \text { المو ارد البيئية } \\
& \text { لا يوضح المعلم لطلابه أهمية الموارد }
\end{aligned}
$$

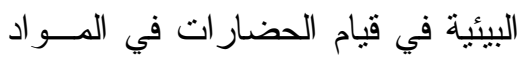

$$
\begin{aligned}
& \text { الدر اسية المختلفة } \\
& \text { • ضعف استشهاد المعلم بأيات قر آنيــة } \\
& \text { عن أهمية البيئة وطرق الحفاظ عليها } \\
& \text { لا يحدد المعلم آداب التعامل مع البيئة } \\
& \text { وفقاً للأحكام الدينية } \\
& \text { لا يوضح المعلم للطــابل المخــاطر } \\
& \text { المترنبة على الاستهلاك السيئ للموارد } \\
& \text { البيئية } \\
& \text { لا يكلف المعلم الطلاب بجمع الــصور }
\end{aligned}
$$

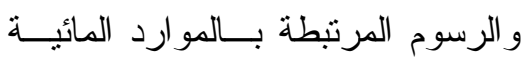

$$
\begin{aligned}
& \text { و المسطحات المائية } \\
& \text { لا يناقش المعلم مع طلابه أهمية علاقة }
\end{aligned}
$$

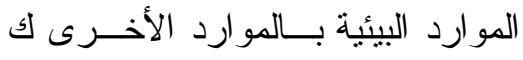

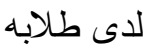


- خلو المناهج من معالجــة المــشكلات

$$
\text { البيئية }
$$

- عدم التزود بالمعارف المتضمنة الأوامر

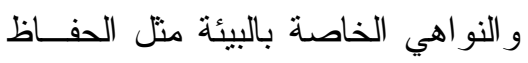

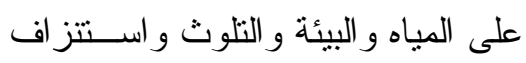

$$
\text { المو ارد }
$$

- خلو المناهج من صيانة البيئة وحمايتها

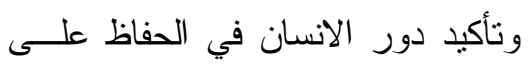
البيئة

\section{المحور الثالث: متطلبـات تحقيـق التزبيـة البيئيـة} بالمعاهد الثانوية الأزهرية - متانية

التزبية البيئيـــة و اســـعة المفهـوم، و و

متعددة المجالات، مختلفة بـاختلاف طبيعــة ولئة

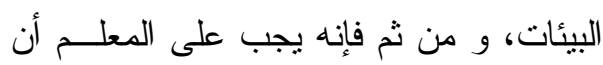

يكون مستعدا للتعامل مع المو اقف المختلفة و

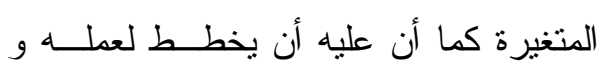
يجعل تخطيطه مرنا حتى يتسع لكل المو اقف

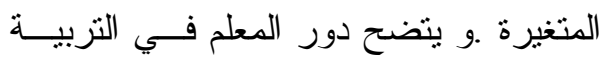
البيئية فيما يلي:

1- إثارة اهتمامات الطلاب نحو بيئـاتهم

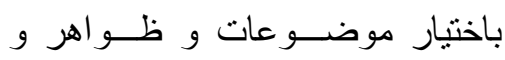

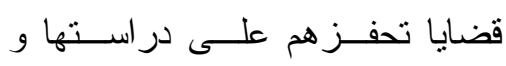
المشاركة في حلها.

ץ- مناقثة خطة الدراسة مع جميع مـن

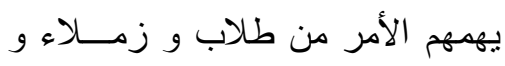
مسؤولين في المدرسة أو في المجتمع

$$
\text { المحلي }
$$

الثزوة السمكية وزيادة الإنتاج الزراعي و الطاقة الكهرومائية) •ا لايوظف المعلم الأحداث الجارية فــي عرض قضايا المو ارد البيئية . • لا يقوم المعلم بتوعية الطلاب بأهميـــة التربية البيئية. ها يعرض المعلم أمثلة للتربية البيئية

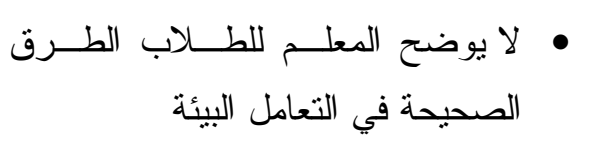
مشكلات خاصة بالمناهج الار اسية: - خلو معظم الدروس المرتبطة بالبيئة من

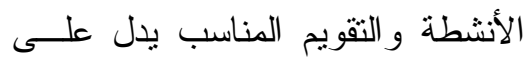
وجود قصور في تحقيق تربيـــة بيئيــة عملية. - أن المفاهيم البيئية في الكتب الدراســية

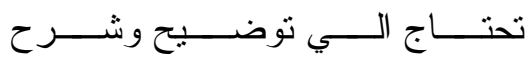
مناسب - وجود قصور حول معالجة المـشكلات البيئية - خلو المناهج مــن المفــاهيم التربويــــة المناسبة الخاصة بالتربية البيئية - لم تحتوي الكتب الدراسية مــن وحــدة متكاملة عن النربية البيئية - خلو المناهج من اتباع الـسلوك البيئـي المناسب اتجاه البيئة 
1 1ا-عمل الترتيبات اللازمة لعرض أعمال

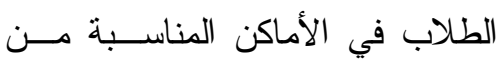

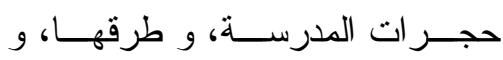

أفنيتها

r إعداد الأدوات و الأجهزة الضرورية

اللازمة للار اسة في البيئة الطبيعيــة

من بوصلات ،و مطارق، و قوارير

و حقائب لحفظ العينات، ...الخ

با - أن يفهم الطالب المعلم وظيفة التزبية

$$
\text { البيئية في تتمية المجتمع لون }
$$

1- أن ينعرف على دور التربية البيئية

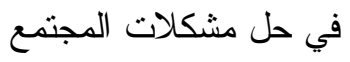

ץ- أن يعرف كيف يـستخدم التربيــة

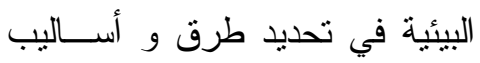

ترشيد استغلال الثزوة الطبيعية في

بيئته

r- أن يكتسب معلومــات و معــارف البيئة و مو اردها الطبيعية

ع- أن يحدد المعتقدات الخاطئة السائدة في بيئته

0- أن يبتخدم التربية البيئية في تعديل

هذه المعتقدات و تكوين الاتجاهات

الايجابية الصحيحة

ج- أن يقدر قيمة التوافق بين مكونــات

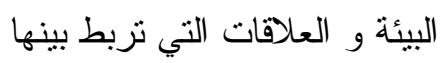

ب- تتظيم الطلاب في مجموعــات عـــل

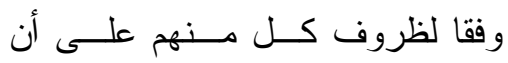

تتكامل الأدوار في النهاية و تتضافر

ع- زيــارة الموقـع المزمــع زيارتــهـه و

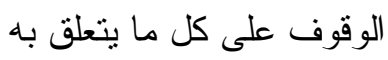

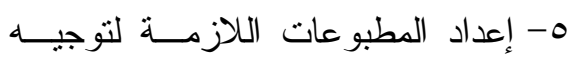

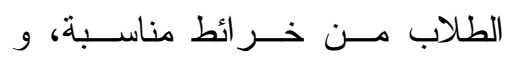

جداول، و إحصائيات، و اسـتنبيانات

الخ...

צ- اتخــاذ التزتيبــات اللازمـــة لـــــوة

متحدثين متخصــصين مسـن البيئــة

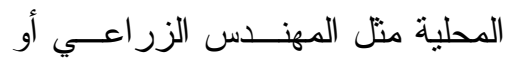

مهندس المباني أو مسؤول الكهربــاء

$$
\text { أو رجل الثرطة،...الخ }
$$

- الاهتمام بصفة خاصة بتدريب التلاميذ

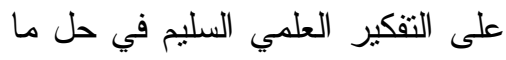

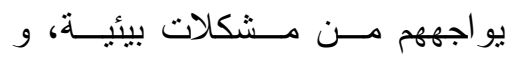

إكسابهم مهار اته، و تتميــة قــدر اتهم

$$
\text { الابتكارية }
$$

^- التركيز على ترشيد الــلوك البيئـي للطلاب فر ادى و جماعات

9- مشاركة الطلاب في كل مر احل العمل

تخطيطا و تتفيذا و تقويما و متابعة هربة

• 1- تتشجيع التناميذ على التعبيــر عـن

أعمالهم و تبادل الخبرات فيما بيــنهم 


$$
\begin{aligned}
& \text { ب- الاهتمام بالقضايا البيئية المعاصــرة }
\end{aligned}
$$

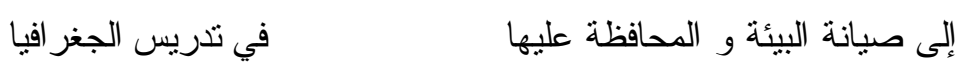

$$
\begin{aligned}
& \text { ـ - إعداد نشر ات دورية للطلاب بــأهم } \\
& \text { الأحداث الجارية المرتبطة بالتربيـــة } \\
& \text { البيئية }
\end{aligned}
$$

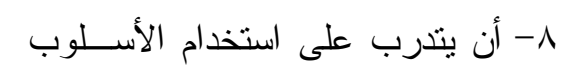

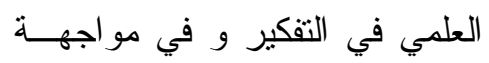

$$
\begin{aligned}
& \text { مشكلات البيئة } \\
& \text { 9- أن يكتسب القدرة على فهم تلاميــذه المراجع }
\end{aligned}
$$

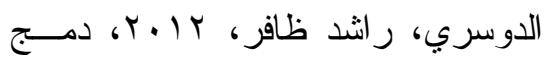

$$
\begin{aligned}
& \text { التربية النربية البيئية في منظومة التعليم }
\end{aligned}
$$

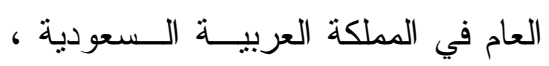

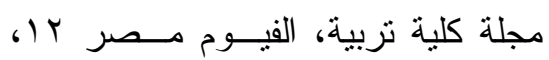

$$
\begin{aligned}
& \Lambda \Lambda-\varepsilon r
\end{aligned}
$$

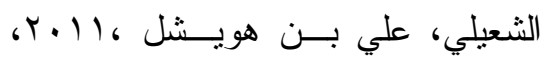

$$
\begin{aligned}
& \text { مساهمة معلمي العلوم في تتمية الــوعي هوبي }
\end{aligned}
$$

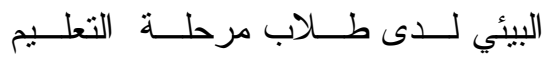

$$
\begin{aligned}
& \text { الأساسي من وجه نظر الطالب ، المجلة }
\end{aligned}
$$

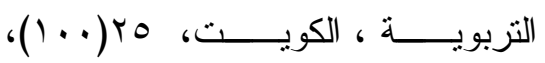

$$
\begin{aligned}
& .17 V_{6} 194 \\
& \text { • أمينة ، كسيرة أمينة ،الاتصلال و التزبية }
\end{aligned}
$$

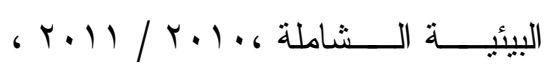

$$
\begin{aligned}
& \text { رسالة مقدمة لنيل شــهادة الماجـستير } \\
& \text { roqur } \\
& \text { • بارك، كرســتوفر • (1987). التربيـــة } \\
& \text { البيئية المشكلات و الأولويات و النوقعات. } \\
& \text { (محمد سعيد صباريني، منرجم). جامعة }
\end{aligned}
$$

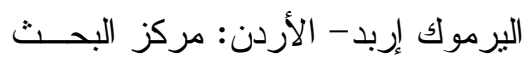

$$
\begin{aligned}
& \text { و التطور التزبوي }
\end{aligned}
$$

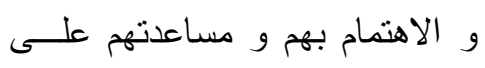

$$
\begin{aligned}
& \text { فهم بيئتهم } \\
& \text { • } 1 \text { - أن يكتــسب مقومـــات الأخــاق }
\end{aligned}
$$

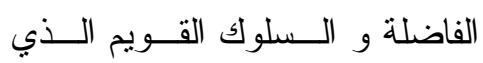

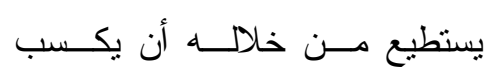

$$
\begin{aligned}
& \text { تلاميذه الخلق البيئي إلى اســتخلا } \\
& \text { البيئة استغلالا حسنا } \\
& \text { 11 - أن يتعرف على دور الــدين فــي }
\end{aligned}
$$

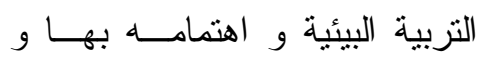

$$
\begin{aligned}
& \text { تأكيده عليها . } \\
& \text { ومنها : } \\
& \text { 1- الاهتمام بتدريب الطلاب بالمعاهــــ } \\
& \text { الاز هرية على كيفية استخدام مداخل } \\
& \text { الأحداث الجارية في تدريس التربية } \\
& \text { البيئية. } \\
& \text { r - عقــد دور ات تدريبيــة للمعلمـين } \\
& \text { للتنريب على كيفية استخدام بر امج } \\
& \text { الوسائط المتعددة وكيفية إعـــداد } \\
& \text { الدروس لاستخدامها فـي تــدريس }
\end{aligned}
$$


•الدمرداش، صبري. (1988). التربيــة

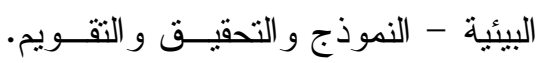
القاهرة: دار المعرفة.

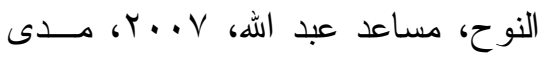

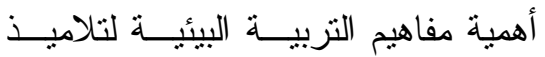

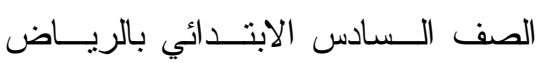

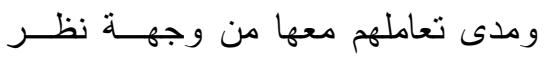

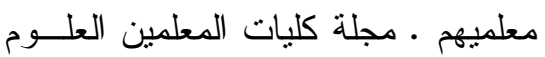

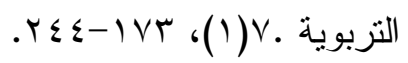

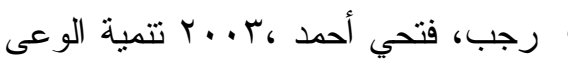
البيئي لطلاب المحلة الثانوية على ضوء التشريعات البيئية المعاصــرة ،رســالة ماجستير غير منشورة ،جامعة المصورة كلية التزبية بدمياط .

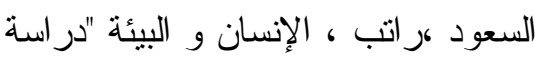

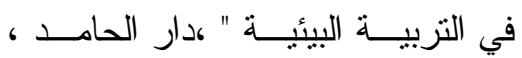
r.v 9 . r...v

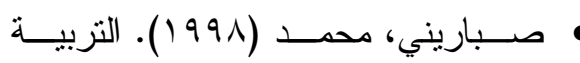
البيئية ـ عمــان : منسشور ات جامعــة القدس المفتوحة. دار الحامد . • صفاحي، إسماعي،2009 ،دور التزبيــة البيئية في حماية البيئة ،المجلة المغربية للإدارة المحلية و التتمية، يونيو، المجلد / لئل

$$
\text { العدد } 86 \text {. }
$$

الطائي، إياد عانشور، و ومحسن عيد علي.

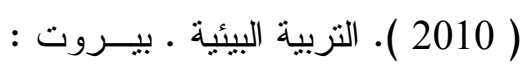
المؤسسة الحديثة للكتاب.
بن حفيظ ، عبد الوهاب، وآخــرون. ( 2005). التربية البيئية في مرحلة التعليم الأساسي بالوطن العربي -دليل مرجعي.

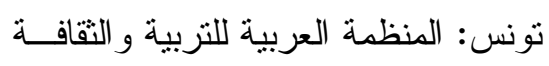
و العلوم. - مون. هبني فارس ، محمود جمعة بن سالم بن

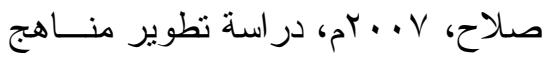

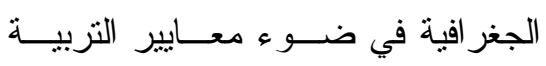
البيئية وقياس فاعلية في تتمية الاتجاهات وتحصيل المفاهيم البيئية وقياس فاعليـــة في تتمية الاتجاهات وتحصيل المفــاهيم البيئية لاى طلبة الصف العاثر الأساسي في الأردن.

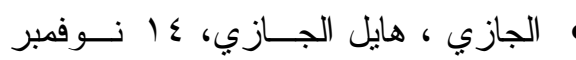
https://mawdoo3.comr • 17

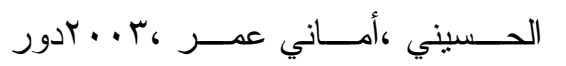

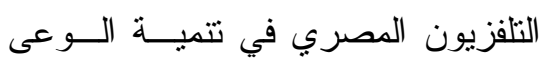

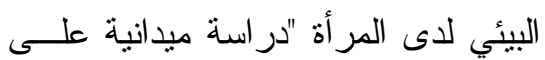

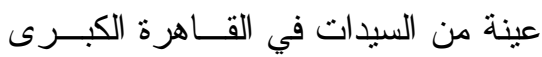

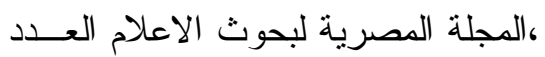

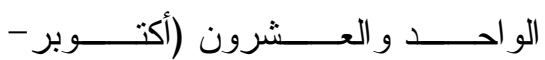
ديسمبر)،جامعة القاهرة، كلية الاعلام

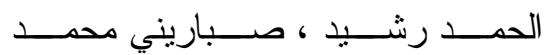
ســعيد،1997 ، البيئـــة و مــشكلاتها،

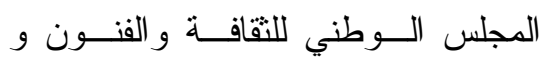
الآداب. 


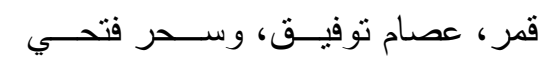

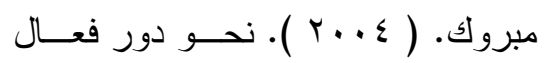

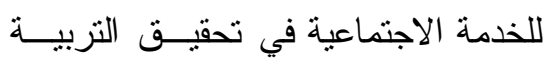

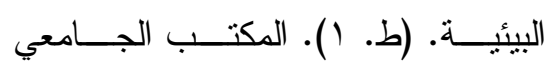
الحديث.

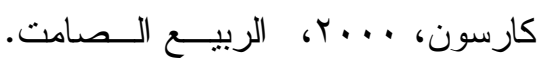

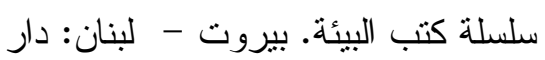

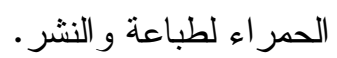

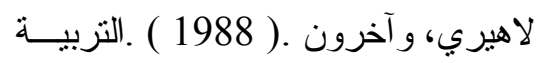

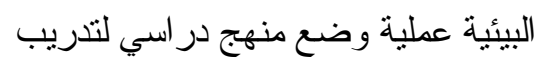
المعلمين قبل الخدمة .البرنامج الــدولي للتربية البيئية المشترك بــين اليونسيكو وبرنامج الأمم المتحدة .سلسلة التربيـــة لئنة البيئية . 26 نشر جامعة إلينوي الجنوبية الو لايات المتحدة الأمريكية اليونسكو. مازن، حسام محمد. ( 2007 ). التربية البيئية- قر اءات در اسات نطبيقات. (ط. (). القاهرة: دار الفجر للنشر و التوزيع.

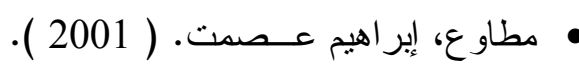
التزبية البيئية فــي الـــوطن العربــي. القاهرة: دار الفكر العربي. • و هيبي، صالح محمود، و إبتسام درويش دهري

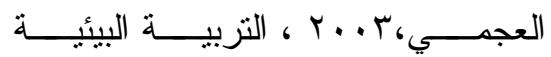

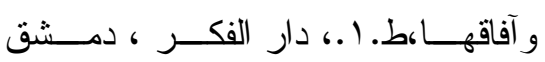
سوريا
طويل ، فتحية طويل ، 2013 التربيـــة

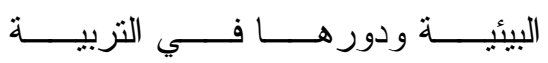

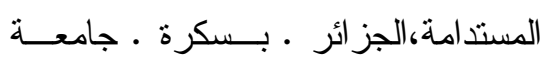

محمد خيضر . ملن

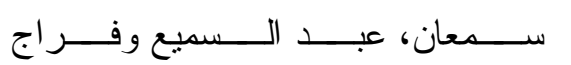

محسن، . . .r،الوعي بالمخاطر البيائيـة

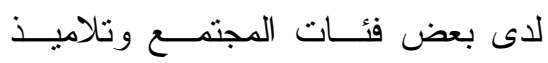

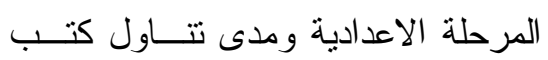

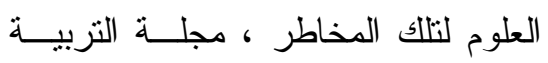
العلمية ، المجلة المصرية للتربية العلمية

$$
. \Sigma \vee-1,(r) 0 \text { ، }
$$

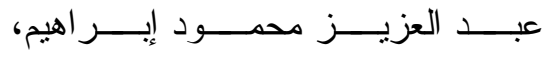

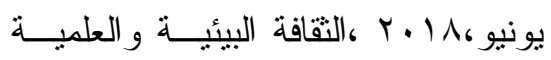
أفاق وتحديات المؤتمر العلمي جامعــة كفر الثيخ. الجمعية المصرية للتربيــة العلمية . لعزية

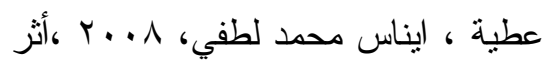

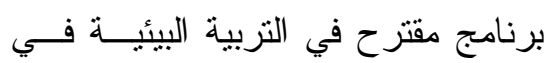
مجال العلوم على تتمية بعض المفــاهيم

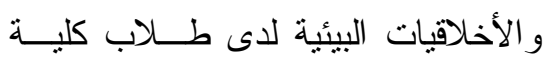

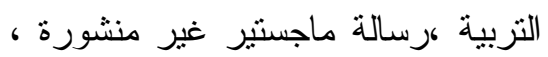
جامعة الزقازيق ،كلية التربية غنايم، مهني محمد إبر اهيم .( 2003 ) .

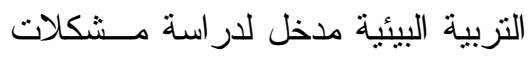
المجتمع سلسلة التربية وقـــايا البيئــة والوعي البيئي) .ط ..1) .القاهرة :الــــار العالمبة للنشر و التوزيع. 
- Cetin gulcan,nisanci Seda hila "2010":Enhancing students environmental awareness

Procedia Social and behavioral Sciences 1830

- Kaurrajinder,Kaur Manpreet (2009) Enviromnental Awareness of secondary and senior Secondary Students, Ejournal Ofindia Assochation For Educational Research,vol 21 no 1

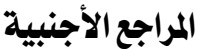

- Anne Scott Sandra, Childrens Environmental Knowing: ACase Study of childrs Experiences During AnEnvironmental Education Promgram, Unpublished philosophy Doctor (ph.D.) Dissertation, University OF British Columbia,Canada, 2007. 